OECD Science, Technology and Industry Working Papers $2000 / 03$

\title{
High-Growth Firms and Employment
}

\section{Paul Schreyer}




\section{Unclassified}

OECD

\section{III} OCDE

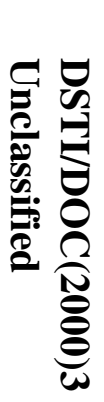

PARIS

Organisation de Coopération et de Développement Economiques

Organisation for Economic Co-operation and Development

DIRECTORATE FOR SCIENCE, TECHNOLOGY AND INDUSTRY

DSTI/DOC(2000)3

OLIS : 30-May-2000

Dist. : 31-May-2000

STI WORKING PAPERS 2000/3

\section{HIGH-GROWTH FIRMS AND EMPLOYMENT}

Paul Schreyer 


\section{STI Working Paper Series}

The Working Papers series of the OECD Directorate for Science, Technology and Industry of the OECD is designed to make available to a wider readership selected studies prepared by staff in the Directorate or by outside consultants working on OECD projects. The papers included in the series are of a technical and analytical nature and deal with issues of data, methodology and empirical analysis in the areas of work of DSTI. The Working Papers are generally available only in their original language English or French - with a summary in the other.

Comment on the papers is invited, and should be sent to the Directorate for Science, Technology and Industry, OECD, 2 rue André Pascal, 75775 Paris Cedex 16, France.

The opinions expressed in these papers are the sole responsibility of the author(s) and do not necessarily reflect those of the OECD or of the governments of its Member countries.

\section{http://www.oecd.org/dsti/sti/prod/sti_wp.htm} to: Head of Publication Service, OECD, 2 rue André-Pascal, 75775 Paris, Cedex 16, France. 


\title{
HIGH-GROWTH FIRMS AND EMPLOYMENT
}

\author{
Paul Schreyer
}

This STI Working Paper deals with this group of rapidly expanding firms. It does so by placing the discussion into a context of entrepreneurship, arguing that there are two main aspects to this notion: one of business start-ups and market entry, and another one of innovation. Evidence is based on results from five OECD countries (Germany, Italy, Netherlands, Spain and Sweden) as well as from Quebec (Canada). Each of these studies used a firm-level data set to identify high-growth firms and their differentiating characteristics. High-growth firms are those firms that rank first according to a measure that combines relative (percentage) and absolute rates of employment expansion.

Despite considerable differences in the underlying data and some of the methodologies, a number of common findings emerge:

- High-growth firms account for a disproportionately large part of gross jobs gained.

- Small firms exhibit higher net job creation rates than large firms do. At the same time, significant flows of gross job gains co-exist with large flows of gross job losses, especially among small firms.

- In absolute terms, larger firms are also significant job creators in the high-growth group. Specifically, they play a more important role as employment creators among high-growth firms than they do among growing firms. On the other hand, the rapid growth of large firms often reflects mergers and acquisitions rather than internal growth.

- High-growth firms are found in all industries and in all regions of the countries examined. Fastgrowing firms tend to be more concentrated in some sectors as opposed to growing firms but the concentration is not necessarily in the same industries.

- High-growth firms are more $R \& D$ intensive than growing firms or than the average permanent firm.

- Firms that are partly or wholly owned by others tend to be more than proportionally represented among the set of fast growers.

- Growing firms tend to be younger than firms on average.

Generally, the study provides evidence of considerable heterogeneity among firms (whether highgrowth or other) which makes any kind of policy that is linked to "common characteristics" hard to formulate and implement. What follows is the importance of policies with framework character to foster the working of markets and to remove unnecessary obstacles to the creation, expansion, development and exit of firms. 


\title{
LES ENTREPRISES A FORTE CROISSANCE ET L'EMPLOI
}

\author{
Paul Schreyer
}

\begin{abstract}
Ce rapport est consacré à la catégorie des entreprises qui connaissent une expansion rapide. Il commence par replacer le propos dans le contexte de l'entrepreneuriat, en partant du principe que la notion d'entreprise à forte croissance comporte principalement deux aspects : i) la création d'entreprise et l'entrée sur le marché ; et ii) l'innovation. Les chiffres présentés sont tirés des résultats d'études portant sur cinq pays Membres de l'OCDE (Allemagne, Espagne, Italie, Pays-Bas et Suède), ainsi que sur le Québec (Canada). Chacune de ces études s'appuie sur des séries de données recueillies auprès des entreprises afin de recenser celles qui ont une forte croissance et de mettre en évidence leurs caractéristiques distinctives. Les entreprises à forte croissance sont celles qui arrivent en tête du classement établi à partir d'une mesure combinée de la croissance relative(exprimée en pourcentage) et de la croissance absolue.
\end{abstract}

En dépit de différences considérables entre les données de base et, parfois, entre les méthodologies employées, on peut dégager un certain nombre de caractéristiques communes :

- La part des entreprises à forte croissance dans les gains bruts d'emplois est supérieure à celle des autres entreprises.

- Les petites entreprises affichent des taux nets de création d'emplois supérieurs à ceux des grandes entreprises. Parallèlement, on constate que des augmentations importantes des gains bruts d'emplois peuvent co-exister avec des variations elles aussi importantes des pertes brutes d'emplois, notamment dans les petites entreprises.

- Dans la catégorie des entreprises à forte croissance, les plus grandes sont elles aussi fortement créatrices d'emplois en valeur absolue. Plus précisément, elles contribuent davantage à la création d'emplois des entreprises à forte croissance que des entreprises en croissance. Cela étant, une croissance rapide dans les grandes entreprises est souvent le résultat d'opérations de fusion et d'acquisition plutôt que d'une croissance interne.

- Dans les pays étudiés, on rencontre des entreprises à forte croissance dans tous les secteurs d'activité et dans toutes les régions. Contrairement aux entreprises en croissance, les entreprises à croissance rapide ont tendance à se concentrer de préférence dans certains secteurs, mais il ne s'agit pas toujours des mêmes.

- Les entreprises à forte croissance investissent davantage en R-D que les entreprises en croissance ou que l'entreprise permanente moyenne.

- Les entreprises partiellement ou entièrement détenues par d'autres sont généralement sur-représentées dans la catégorie des entreprises à croissance rapide.

Les entreprises en croissance sont généralement plus jeunes que la moyenne. D'une manière générale, l'étude met en évidence l'hétérogénéité importante entre firmes, que leur croissance soit forte ou non. Ceci rend plus difficile la formulation et la mise en œuvre de toute mesure politique fondée sur des "caractéristiques communes" entre entreprises. Par conséquent, les mesures politiques concernant les conditions-cadre qui visent à soutenir le fonctionnement des marchés et qui sont destinées à démanteler des obstacles - parfois difficilement justifiables - à la création, à l'expansion, au développement et au retrait des entreprises du marché, deviennent encore plus importantes. 


\section{TABLE OF CONTENTS}

\section{HIGH-GROWTH FIRMS AND EMPLOYMENT}

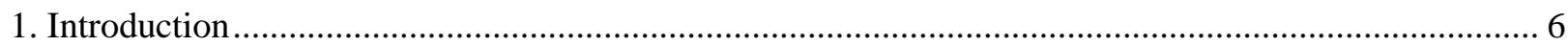

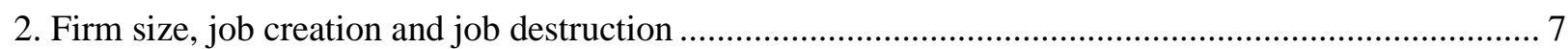

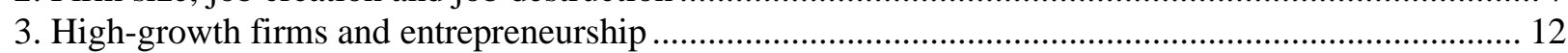

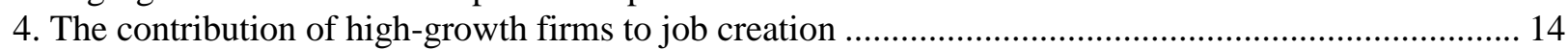

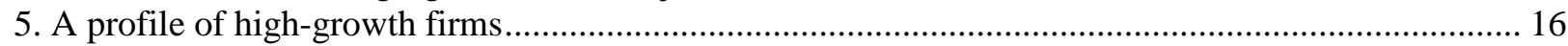

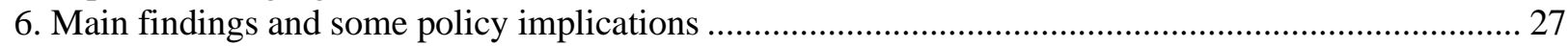

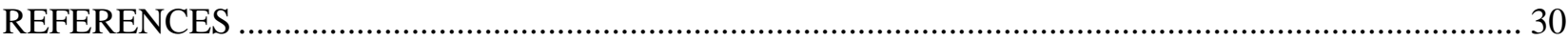

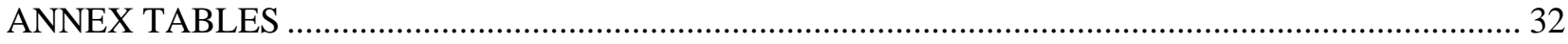

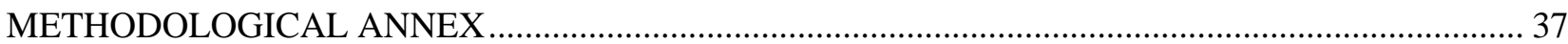




\section{HIGH-GROWTH FIRMS AND EMPLOYMENT}

\section{Introduction ${ }^{1}$}

Structural unemployment and weak employment growth have been salient characteristics of labour market developments in many OECD countries. There are a number of explanations for this problem, including macro-economic conditions, the functioning of labour and product markets and the effects of technological change and globalisation. All of these aspects have been investigated in recent years, including by in-depth work carried out by the OECD. ${ }^{1}$ One general conclusion from the different studies is that unemployment often reflects a lack of economies' capacity to adapt to change. The degree at which economies are adaptable depends on the nature of institutions, structural policies, regulations and legal settings as well as social and cultural values.

Governments can influence incentives and framework conditions that bear on an economy's capacity to adapt but the actual implementation of change rests with private agents. Some of the most important agents of change are entrepreneurs - individuals with the capacity and willingness to take risks, to be innovative and to exploit business opportunities in a market environment. By its very nature, entrepreneurship implies uncertainty and an uneven distribution of information about business opportunities. Hence, entrepreneurship is an idiosyncratic process, confirmed by the large differences in firm performance found by most empirical studies on the subject.

Inter-firm differences also loom large when it comes to employment dynamics. Where micro-level data have been employed to track the generation and losses of jobs, a common observation across countries, industries or time periods has been the co-existence of job creation and job losses and, more generally, a picture of significant variance in growth and job creation performance of firms, even if they operate in the same, narrowly defined market. ${ }^{2}$ In line with the image of heterogeneity has been the empirical observation that there is typically a small group of firms that are responsible for a large share of new jobs created. These rapidly expanding firms, by way of their supposed or actual potential to generate jobs, have attracted the attention of policy makers, eager to reduce unemployment.

The present work focuses on this group of rapidly expanding firms and does so by placing the discussion into a context of entrepreneurship. There are two main aspects to this notion: one of business start-ups and market entry, and another one of innovation. Both aspects are current in the literature and provide plausible characterisations of entrepreneurship. In the present report, then, rapid growth is understood as entrepreneurial success. The main objective is to analyse the sets of the fastest growing firms as identified in each of the country studies. In addition, new evidence on the relation between firm growth and firm size complements findings from the existing literature.

1. This report is based on a project carried out by the OECD Working Party on Small and Medium-Sized Enterprises. Under the project, researchers from six participating countries carried out national studies on the topic of high growth firms and employment: Canada (Quebec), France, Italy, the Netherlands, Spain and Germany (see Annex for a more complete list of authors of underlying studies). In several respects, this working paper constitutes an interim report and a final report - forthcoming in the course of 2000 will extend the present work to cover an additional country (Greece) and to take account of a statistical survey carried out in several countries with a view to further exploring the characteristics of high-growth firms. 
Section 3 of the document starts out with the more general analysis of firm size and firm growth. Section 4 focuses on fast-growing firms, discussing how to identify them, their contribution to employment gains and examining differentiating characteristics. Section 5 provides conclusions and tentative policy implications.

\section{Firm size, job creation and job destruction}

\section{1 .Background}

Since statistical tools and data sets have become available that permit the tracing of the employment history and growth of individual firms, a number of studies have investigated the micro-level aspects of job creation and destruction. One of the firm characteristics that has attracted most attention by policy makers is firm size - unsurprisingly, given that many countries have constructed and conducted policies for small and medium-sized firms and so used "size" as an important differentiating characteristic. One of the rationales for doing so has been to counterbalance actual or perceived biases against small firms as they may arise from certain regulations, fiscal or labour market policies. Another reason put forward in favour of SMEs has been their role in the job generation process. Ever since the work of David Birch (1981), who pointed out that, in the United States, small businesses had been a disproportionately large source of job creation, there has been a debate about the robustness of these results with respect to their validity across countries, sectors and over time. Earlier OECD work (OECD, 1994b; OECD, 1997b) provided an overview of different studies and the present study is an additional opportunity to gather evidence on this question.

To explore the issue, several distinctions must be made. First, flows of gross job creation and gross job losses have to be distinguished from net job creation. Significant flows of gross job creation co-exist with flows of gross job losses. Although net job creation (the difference between job gains and job losses) is a frequent focus, the examination of gross flows can be of interest for policy makers: simultaneous job creation and job destruction reveals a considerable amount of churning in labour markets. Such churning is an expression of the competitive process and entrepreneurship and examining its extent and development can be of interest. A look at gross flows also brings out the heterogeneity between firms, even if they are in the same industry, or of the same size and age. The observation of such diversity, in turn, sheds doubt on policy formulations that rest mainly on the vision of an "average" or "typical" firm.

Second, and turning to the issue of net job creation, a measure has to be defined that reflects the relative importance of small and large firms in the job creation process. The most common measure is one of net job creation rates for different firm characteristics, in particular for different size classes. Net job creation rates are percentage ratios that relate net job gains to the total number of employed. One should note, however, that a large net job generation rate does not necessarily imply a large absolute contribution to the overall number of net jobs created, as absolute contributions are the product of net job creation rates and the share that a category occupies in total employment. Thus, a size category that accounts for a small share of initial employment but has a high net job creation rate may still have a small impact on overall job creation whereas a size category that stands for a large share of employment may contribute significantly to overall net job creation, even if its net job creation rate is low.

\subsection{Aggregate flows of job gains and losses}

With these observations in mind, some results from the six countries can be examined, starting with a review of gross job flows. Table 1 presents some basic information about the samples of firms that were investigated in the seven country studies. These samples are not identical - they vary in several respects, including their sectoral coverage, the time period they cover and the size of the sample relative to the 
overall population of firms (see Annex for details). As a consequence, cross-country comparisons have to be carried out with some caution. Notwithstanding these differences, there are some common salient features, most of which confirm earlier work in the area:

- At the aggregate level but also (as will be documented later) at the more detailed sectoral level or for individual size classes, gross flows of job creation co-exist with flows of job losses. This is a clear indication of considerable heterogeneity among firms and an expression of market dynamics at work.

- Net employment gains or losses are significantly smaller than gross flows of job creation and destruction or job turnover, the combined measure of job gains and losses: across the examined countries, job turnover rates are of a magnitude of about 5\% per year whereas net job creation rates average about $-1 \%$. These are still much smaller figures than those resulting from other studies, for example the survey in OECD (1996b) which shows job turnover rates in the order of 20 and 30\% per year, depending on countries. Much of this difference is due to the size class coverage of the samples shown in Table 1: they relate to firms of 20 employees or more, leaving out the much more volatile size classes of very small and micro firms. Furthermore, the studies in Table 1 are based on permanent firms only - and an important part of gross flows of job gains and job losses stem from openings and closures of firms (OECD, 1996b; OECD, 1994b).

\subsection{Job gains and job losses by firm size}

Similar to the aggregate level, significant flows of gross job gains and gross job losses co-exist within size classes. This is apparent from the job flows shown in Figure 1 and Table 1. The implication is that it is not an entire size cohort that creates or loses jobs but only a subset of firms in that size cohort. Another consequence is that job turnover rates are comparatively high even within size classes and other subcategories of firms. This can be taken as one of the manifestations of market dynamics, and of an ongoing search process for business opportunities and entrepreneurship. This observation will be helpful in interpreting the role that the set of rapidly expanding firms play in the generation of employment and growth.

Also, both the rates of gross job gains and gross job losses tend to become smaller with increasing firm size. Put differently, there is a greater degree of turbulence or job turnover in smaller size classes. The difference in turbulence is attenuated, however, by the fact that the underlying samples are confined to permanent firms of a minimum size of 20. Inclusion of entries and smaller size classes typically results in much larger measures of gross flows of job gains and losses. 
Table 1. Job flows in data sets for seven Member countries

Permanent firms with at least 20 employees

\begin{tabular}{|c|c|c|c|c|c|c|c|}
\hline & FRANCE & CANADA (Quebec) & ITALY & NETHERLANDS & SPAIN & SWEDEN & GERMANY \\
\hline Period under review & 1985-94 & $1990-96$ & $1990-95$ & $1989-94$ & $1990-94$ & $1987-96$ & 1993-95 \\
\hline Number of permanent firms & 10691 & 2977 & 29690 & 23416 & 1174 & 8173 & 788 \\
\hline $\begin{array}{l}\text { Number of employees at the beginning of the } \\
\text { period }\end{array}$ & 2413238 & 322921 & 2598414 & 2403746 & 291545 & 958072 & 6520000 \\
\hline Number of employees at the end of the period & 2118070 & 310505 & 2516014 & 2441098 & 246283 & 995037 & 6010000 \\
\hline Total job gains & 257411 & 43371 & 408674 & 311349 & 51006 & 266515 & 360000 \\
\hline Total job losses & 552579 & 55787 & 491074 & 273996 & 96268 & 229550 & 870000 \\
\hline Net job creation/losses & -295168 & -12416 & -82400 & 37354 & -45262 & 36965 & -510000 \\
\hline Annualised gross job creation rate & $1.26 \%$ & $2.28 \%$ & $3.19 \%$ & $2.57 \%$ & $4.65 \%$ & $3.04 \%$ & $2.82 \%$ \\
\hline Annualised rate of gross job losses & $2.69 \%$ & $2.93 \%$ & $3.83 \%$ & $2.27 \%$ & $8.78 \%$ & $2.62 \%$ & $6.81 \%$ \\
\hline Annualised rate of job turnover & $3.95 \%$ & $5.20 \%$ & $7.01 \%$ & $4.84 \%$ & $13.44 \%$ & $5.66 \%$ & $9.62 \%$ \\
\hline Annualised net job creation rate & $-1.44 \%$ & $-0.65 \%$ & $-0.64 \%$ & $0.31 \%$ & $-4.13 \%$ & $0.42 \%$ & $-3.99 \%$ \\
\hline
\end{tabular}

1.For a description of the data sets and sources, see Annex 1.

Source: OECD, based on country studies. 
Table 2. Job flows by firm size

\begin{tabular}{|c|c|c|c|c|c|c|}
\hline \multicolumn{7}{|c|}{ France (1985-94) } \\
\hline Employment size class & $\begin{array}{l}\text { Annualised rate of } \\
\text { gross job gains }\end{array}$ & $\begin{array}{c}\text { Annualised rate of } \\
\text { gross job losses }\end{array}$ & $\begin{array}{l}\text { Annualised rate of } \\
\text { net job gains/losses }\end{array}$ & $\begin{array}{l}\text { Annualised rate of } \\
\text { job turnover }\end{array}$ & $\begin{array}{l}\text { Contribution to } \\
\text { gross job gains }\end{array}$ & $\begin{array}{l}\text { Contribution to } \\
\text { gross job losses }\end{array}$ \\
\hline $20-49$ & $3.3 \%$ & $3.9 \%$ & $-0.6 \%$ & $7.1 \%$ & $20.2 \%$ & $11.0 \%$ \\
\hline $50-99$ & $2.8 \%$ & $2.7 \%$ & $0.1 \%$ & $5.5 \%$ & $16.6 \%$ & $7.4 \%$ \\
\hline $100-249$ & $2.1 \%$ & $1.6 \%$ & $0.5 \%$ & $3.7 \%$ & $21.4 \%$ & $7.6 \%$ \\
\hline $250-499$ & $2.0 \%$ & $1.6 \%$ & $0.4 \%$ & $3.6 \%$ & $17.9 \%$ & $6.6 \%$ \\
\hline 500-1999 & $1.1 \%$ & $0.3 \%$ & $0.8 \%$ & $1.4 \%$ & $17.7 \%$ & $2.3 \%$ \\
\hline \multirow[t]{2}{*}{$2000+$} & $0.2 \%$ & $4.3 \%$ & $-4.1 \%$ & $4.5 \%$ & $6.1 \%$ & $65.1 \%$ \\
\hline & & & & & $100.0 \%$ & $100.0 \%$ \\
\hline
\end{tabular}

\begin{tabular}{|c|c|c|c|c|c|c|}
\hline \multicolumn{7}{|c|}{ Canada (Québec) (1990-96) } \\
\hline Employment size class & $\begin{array}{l}\text { Annualised rate of } \\
\text { gross job gains }\end{array}$ & $\begin{array}{l}\text { Annualised rate of } \\
\text { gross job losses }\end{array}$ & $\begin{array}{l}\text { Annualised rate of } \\
\text { net job gains/losses }\end{array}$ & $\begin{array}{c}\text { Annualised rate of } \\
\text { job turnoverl }\end{array}$ & $\begin{array}{l}\text { Contribution to } \\
\text { gross job gains }\end{array}$ & $\begin{array}{l}\text { Contribution to } \\
\text { gross job losses }\end{array}$ \\
\hline $20-49$ & $4.1 \%$ & $2.0 \%$ & $2.1 \%$ & $6.1 \%$ & $25.9 \%$ & $9.7 \%$ \\
\hline $50-99$ & $3.3 \%$ & $2.3 \%$ & $1.0 \%$ & $5.6 \%$ & $19.7 \%$ & $10.8 \%$ \\
\hline $100-199$ & $2.4 \%$ & $2.8 \%$ & $-0.3 \%$ & $5.2 \%$ & $23.1 \%$ & $20.2 \%$ \\
\hline $200-499$ & $1.7 \%$ & $3.0 \%$ & $-1.3 \%$ & $4.7 \%$ & $18.1 \%$ & $25.2 \%$ \\
\hline $500+$ & $1.1 \%$ & $3.8 \%$ & $-2.7 \%$ & $4.9 \%$ & $13.2 \%$ & $34.0 \%$ \\
\hline & & & & & $100.0 \%$ & $100.0 \%$ \\
\hline
\end{tabular}

\begin{tabular}{|c|c|c|c|c|c|c|}
\hline \multicolumn{7}{|c|}{ Italy (1990-95) } \\
\hline Employment size class & $\begin{array}{l}\text { Annualised rate of } \\
\text { gross job gains }\end{array}$ & $\begin{array}{l}\text { Annualised rate of } \\
\text { gross job losses }\end{array}$ & $\begin{array}{l}\text { Annualised rate of } \\
\text { net job gains/losses }\end{array}$ & $\begin{array}{c}\text { Annualised rate of } \\
\text { job turnoverl }\end{array}$ & $\begin{array}{l}\text { Contribution to } \\
\text { gross job gains }\end{array}$ & $\begin{array}{l}\text { Contribution to } \\
\text { gross job losses }\end{array}$ \\
\hline $20-49$ & $3.9 \%$ & $2.7 \%$ & $1.2 \%$ & $6.5 \%$ & $27.7 \%$ & $15.9 \%$ \\
\hline $50-99$ & $4.3 \%$ & $2.8 \%$ & $1.5 \%$ & $7.1 \%$ & $21.0 \%$ & $11.5 \%$ \\
\hline $100-199$ & $3.2 \%$ & $3.1 \%$ & $0.1 \%$ & $6.4 \%$ & $14.5 \%$ & $11.8 \%$ \\
\hline $200-499$ & $3.2 \%$ & $3.7 \%$ & $-0.5 \%$ & $6.8 \%$ & $15.5 \%$ & $15.0 \%$ \\
\hline 500-999 & $2.8 \%$ & $4.7 \%$ & $-1.9 \%$ & $7.5 \%$ & $7.5 \%$ & $10.6 \%$ \\
\hline \multirow[t]{2}{*}{$1000+$} & $1.9 \%$ & $5.9 \%$ & $-4.0 \%$ & $7.9 \%$ & $13.9 \%$ & $35.2 \%$ \\
\hline & & & & & $100.0 \%$ & $100.0 \%$ \\
\hline \multicolumn{7}{|c|}{ Netherlands (1989-94) } \\
\hline Employment size class & $\begin{array}{l}\text { Annualised rate of } \\
\text { gross job gains }\end{array}$ & $\begin{array}{l}\text { Annualised rate of } \\
\text { gross job losses }\end{array}$ & $\begin{array}{l}\text { Annualised rate of } \\
\text { net job gains/losses }\end{array}$ & $\begin{array}{c}\text { Annualised rate of } \\
\text { job turnover }\end{array}$ & $\begin{array}{l}\text { Contribution to } \\
\text { gross job gains }\end{array}$ & $\begin{array}{l}\text { Contribution to } \\
\text { gross job losses }\end{array}$ \\
\hline $20-49$ & $3.3 \%$ & $2.0 \%$ & $1.3 \%$ & $5.3 \%$ & $15.9 \%$ & $11.0 \%$ \\
\hline $50-99$ & $3.3 \%$ & $1.9 \%$ & $1.4 \%$ & $5.2 \%$ & $13.4 \%$ & $8.6 \%$ \\
\hline 100-199 & $2.8 \%$ & $2.4 \%$ & $0.3 \%$ & $5.2 \%$ & $10.5 \%$ & $10.5 \%$ \\
\hline $200-499$ & $2.7 \%$ & $2.3 \%$ & $0.4 \%$ & $5.0 \%$ & $12.7 \%$ & $12.3 \%$ \\
\hline \multirow[t]{2}{*}{$500+$} & $2.2 \%$ & $2.4 \%$ & $-0.1 \%$ & $4.6 \%$ & $47.5 \%$ & $57.5 \%$ \\
\hline & & & & & $100.0 \%$ & $100.0 \%$ \\
\hline
\end{tabular}

1.For France, gross job losses and net job gains/losses reflect also employment changes between size classes Source: OECD, based on country reports. 


\section{Box 1. Allocation of firms to size classes: two different views}

An important technical issue in studies on net job creation rates is how firms are allocated to size classes: for example, a firm can be considered "small" if it corresponds to the criterion "small" in some base year. Any subsequent job creation is then attributed to the size class "small", irrespective of whether the firm has moved to a different size class by the end of the observation period. Alternatively, a firm can be considered "small" if it corresponds to the criterion "small" on average, over the entire period. It has been shown that net job creation rates of small and large firms are sensitive to such changes in the size class allocation of firms, a methodological point that has raised a substantive amount of discussion. Opinions are still divided on this matter, although most authors acknowledge the importance of this methodological matter. Two views prevail:

In one view, ${ }^{3}$ employment often fluctuates from year-to-year, owing to variation in demand and other factors. In this case, average rather than current plant size provides the appropriate indication of the production unit's intended scale of operations and minimises the measurement error due to transitory components. In statistical terms, what is being assumed here is that the pattern of employment exhibits random fluctuations around a trend, resulting in what is called a "regression-to-the mean" bias in the data. For example, some firms that are identified as small at a certain point in time will be so because they are in a transitory downturn, so that the random component is negative. However, these "small" firms will return to their "typical" size in the future. The result is that, overall, small firms will appear to grow disproportionately and the performance of large firms will appear to be rather poor. Note that this view, implicitly or explicitly, subscribes to the existence of an equilibrium path that firms follow, at least in the long run. It also implies that at least part of the observed turbulence in gross job flows is "noise", caused by shocks (exogenous, such as business cycles or endogenous such as productivity shocks or adjustment costs) that prevent firms from adhering to their equilibrium path of expansion or contraction. This observation is of consequence to the discussion of turbulence, which in turn has policy implications.

Another view sees a more turbulent system in which change is the normal state of affairs and owners or entrepreneurs adjust employment to maximise profits: they increase employment as demand increases and workers are available and decrease employment as demand drops to reduce costs. To capture changes precisely, frequent observations are needed. The most appropriate measure of size may be the one taken at the beginning of each year (base-year size) over the observation period. This is the firm's size before employment is adjusted in response to changing cost factors or market opportunities. ${ }^{4}$ This view corresponds to a more evolutionary vision of the market process or, in its purest form, to an Austrian vision of markets (a recent overview can be found in Kirzner (1997)): in an environment of permanent change of tastes, technologies and institutions, firms discover opportunities as they are active in the market place and aim at exploiting them. Uncertainty and idiosyncrasy prevail and characterise the market process. The notion of competition is linked to this process and, by definition, there can be no equilibrium state or path towards which firms or industries would converge. As a consequence, the rationale for choosing average size as the criterion for allocating units to size classes loses its relevance. 
Further, net job creation rates tend to decline with firm size. In other words, the probability for smaller size classes to exhibit net job gains is higher than for larger firms. The combined effect of a comparatively high net job creation rate and a large share in total employment shows up in significant contributions of smaller size classes to total job gains and relatively smaller contributions in total job losses. This is in line with much of the relevant literature, although several caveats are called for:

- Firstly, the choice of the definition of size classes can, in principle, alter a picture of net job creation rates that fall as one moves from smaller to larger size classes. The issue can be avoided by applying regression techniques to bring out a single statistical relationship between firm growth and firm size. A recent German study (Harhoff et al., 1998) used this approach but found that the negative size-growth relationship persists. Similarly, the studies by Evans (1987) and by Dunne et al. (1989) find that larger firms (plants) have lower growth rates.

- Secondly, the relationship between firm size and net job creation is not always linear. For example, the smallest and the largest size class in the French sample have been shedding jobs whereas net job creation rates where highest in the 500-1999 size cohort. Conversely, in the study on Germany by Harhoff et al. (1998), net job creation rates are highest for the smallest and for the largest firm sizes and a U-shaped relationship appears.

- Thirdly, a negative relationship between job creation and firm size can reflect other firm characteristics that are partly or entirely correlated with size and whose effects the present computations are picking up. One candidate for such a variable is age, because nearly all young firms are small and most larger firms are old. Analysis of German data shows, for example, that average rates of net job creation ${ }^{5}$ decline both with firm size and with firm age. To shed light on this issue, age and size have to be examined jointly as determinants of firm growth. Studies that have proceeded along these lines usually find that both size and age have significant and independent negative effects on firm growth. ${ }^{6}$

\section{High-growth firms and entrepreneurship}

Entrepreneurship, the process of identifying economic opportunities is central to the functioning of market economies (OECD, 1998a). Entrepreneurs not only seek out and identify potentially profitable opportunities, but also assume risks in realising their judgements. While not all will succeed, a country characterised by substantial entrepreneurial activity is likely to be constantly generating new services and products to replace older ones. Such a process clearly covers all economic activity and is not just confined to high-technology activities or particular business functions. Moreover, entrepreneurship can characterise the actions of companies, new and well established, small and large. In view of the breadth of the nature of the concept, no precise measurement of entrepreneurship is available. However, in empirical applications, there have been two recurring features in characterising entrepreneurship: new or young firms and innovation.

\subsection{Entrepreneurial aspects (1): new and young firms}

Entrepreneurship is frequently associated with the process of business start-ups and business creation. These are important manifestations of entrepreneurial activity. As empirical studies have shown, de-novo entrants are nearly always small. Audretsch (1995), for example, operationalises entrepreneurship as the extent to which an industry is comprised by new and young firms, thus placing the age of the enterprise as the central parameter defining entrepreneurial activity. How does this aspect of age carry over to the discussion of rapidly expanding firms and job creation? It is possible to identify the set of these fast 
growers and to assess their contribution to overall employment growth. This provides a useful link between business start-ups and employment creation and leads directly to the discussion of young firms with exceptional growth performance. Even if direct, short-term employment effects of such gazelles may be small, they attract much policy interest because they tend to produce indirect and spill-over effects, as is for example the case for fast-growing technology-based firms. ${ }^{7}$. Policy implications bear, for example, on the gestation, start-up and expansion phase in the life-cycle of firms.

By its very nature, a systematic investigation of young, fast-growing firms requires data on firm entry and growth patterns among very small units. ${ }^{8}$ Consequently, data sets that consist of permanent firms and/or firms with minimum size are badly suited to capture the influence and differentiating characteristics of new and young firms. Much of the dynamics due to new entries and due to the inclusion of very small size classes would go unnoticed. With some exceptions (Germany, Sweden), national studies and data sets were limited in just this way and their use to investigate gazelles would have been limited. Thus, the focus of the present study is on a different aspect of entrepreneurship, namely innovation, whose analysis depends to a much lesser degree on data on firm entry.

\subsection{Entrepreneurial aspect (2): innovation}

The second aspect of entrepreneurship is innovation. For the present purpose, innovation is understood in a broad sense to cover technical advances to products and processes, the development of entirely new products, but also organisational or marketing innovations. If entrepreneurial activity is understood as the capacity and willingness to take risks, to be innovative and to exploit business opportunities in a market environment, well-established and large firms play an important part as entrepreneurs. Empirically, it appears that above a certain threshold of firm size, R\&D rises more or less proportionally with size (Symeonidis, 1996). Even if one takes account of the fact that R\&D is a measure of input rather than innovation output, and if one uses more output-oriented measures, the proportional relationship with size tends to hold. Several surveys of the relevant literature (e.g. Symeonidis, 1996; Cohen, 1995; Cohen and Levin,1989) have reinforced the consensus that, on average, there is no apparent advantage to size in the innovation process. This is not to say that, for specific activities, size does not matter: in the presence of large fixed costs to innovative activity (e.g. in pharmaceuticals), large firms will have an advantage; when it comes to flexibility and the ability to exploit niches, small firms are likely to emerge as innovators. Thus, while size does play a role for different types of innovation processes, the relationship can go different ways and it is difficult to establish a-priori whether entrepreneurial activity is negatively or positively related to firm size.

In practical terms then the challenge is to choose an indicator that identifies rapidly expanding firms in a way that is consistent with the above observations on the relationship between innovation and firm size. In particular, a growth measure that is supposed to reflect the effects of successful innovation should not a-priori favour a particular firm size. To this end, a combined measure of absolute and relative growth was adopted (see Box 2). The idea is to allow for cases where market opportunities or new projects are of a certain size, so that their realisation can only be carried out by larger firms. Successful innovation will then not necessarily translate into large percentage growth rates but will also be recognised if the absolute expansion is important. 


\section{Box 2. Measures of growth}

One way of explaining firm growth is to stress the role of markets as pools of new opportunities (e.g. Sutton (1995)) and to treat innovation as the capacity to seize these opportunities. As it is difficult to establish a-priori whether entrepreneurial activity is negatively or positively related to firm size, a growth measure that is supposed to reflect the effects of successful innovation should not a-priori favour a particular firm size.

Consider the proportional (percentage) rate of change as a measure of growth. If it was an appropriate measure for the effects of innovation, then it should be independent of firm size. It is easy to argue that, in a set of growing firms, small units are much more likely to exhibit high rates of percentage growth than large ones. Thus, using proportional growth rates to identify high-growth units would imply a bias towards small firms.

By the same token it can be argued that absolute growth, measured in changes in the number of employees, leads to a bias towards large firms. For the present project then, a combined measure of absolute and relative growth was chosen, following the French country report and earlier work by Birch (1987). This growth indicator is defined as $m=\left(x_{t_{1}}-x_{t_{0}}\right) \frac{x_{t_{1}}}{x_{t_{0}}}$ where $x_{t_{1}}$ and $x_{t_{0}}$ denote employment size by the end and the beginning of the sample period. It can be demonstrated that this measure, while still dependent on firm size, always gives rise to a smaller bias towards any size class than either the relative or the absolute measure of growth. ${ }^{9}$

\section{The contribution of high-growth firms to job creation}

For each country, a set of rapidly expanding units was identified by ranking firms on the basis of the above indicator of expansion and by choosing the top $10 \%$ of this distribution. It was then possible to assess the role of these rapidly expanding firms in job creation and to study some of their differentiating characteristics. A first impression of the role of rapidly expanding firms is given in Figure 1 and Figure 2. They present the share of fast growers in the total number of firms (Figure 1) - a percentage dictated by the definition of the set of high-growth firms, and correspond for example to the top $10 \%$ growers of all firms in the Spanish sample or to the top 5\% in the Dutch case. The share in base year employment (2nd bar) occupied by these firms exceeds the share in the number of firms for all countries except Spain. This signals already that the average (employment) size of fast growers exceeds the average size of the entire sample.

In the case of the Netherlands, which stands out with a particularly large difference, the average firm size in the sample is around 100 employees in the base year. Average size of all growing firms is smaller, around 70 whereas the average size of fast-growing units is 480 employees. This is a consequence of the choice of the growth index, which is designed to capture expansion of both small and larger firms, but which produces a very large share of fast growers among the large firms. While this can be held against the construction of the index, it also reveals an interesting feature of the Dutch case: however defined, fast growers are either relatively large firms or quite small ones but not middle-sized units between 50 and 100 employees. 
Figure 1. High-growth firms as a share of permanent firms

\section{Percentage shares}

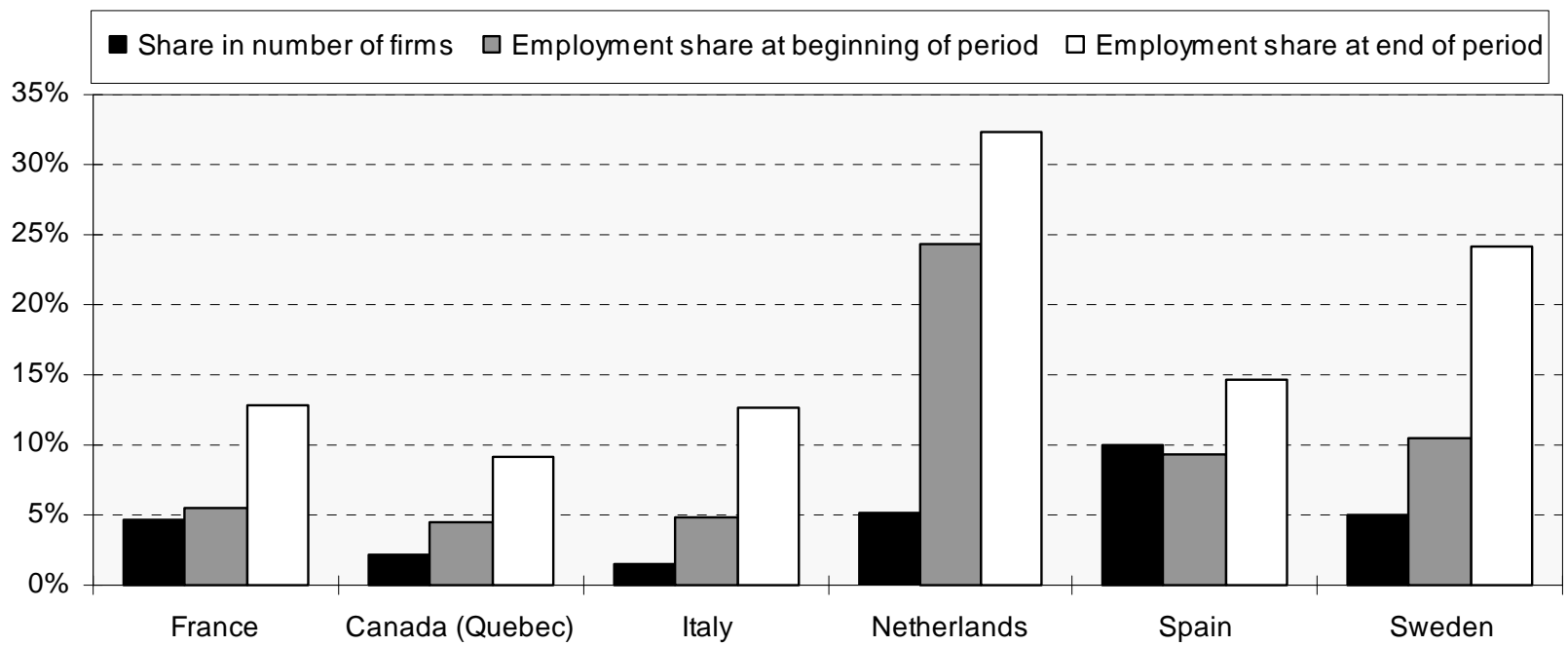

Source: OECD, based on country studies.

Note : Initial shares of high-growth firms reflect definitional differences in country studies. For example, in France, highgrowth firms were defined as the top $10 \%$ of all growing firms whereas in Spain they were selected as the top $10 \%$ of all firms, whether growing or not. Consequently, the level of these shares should not be compared across countries.

Figure 2. High-growth firms as a share of growing firms

Percentage shares

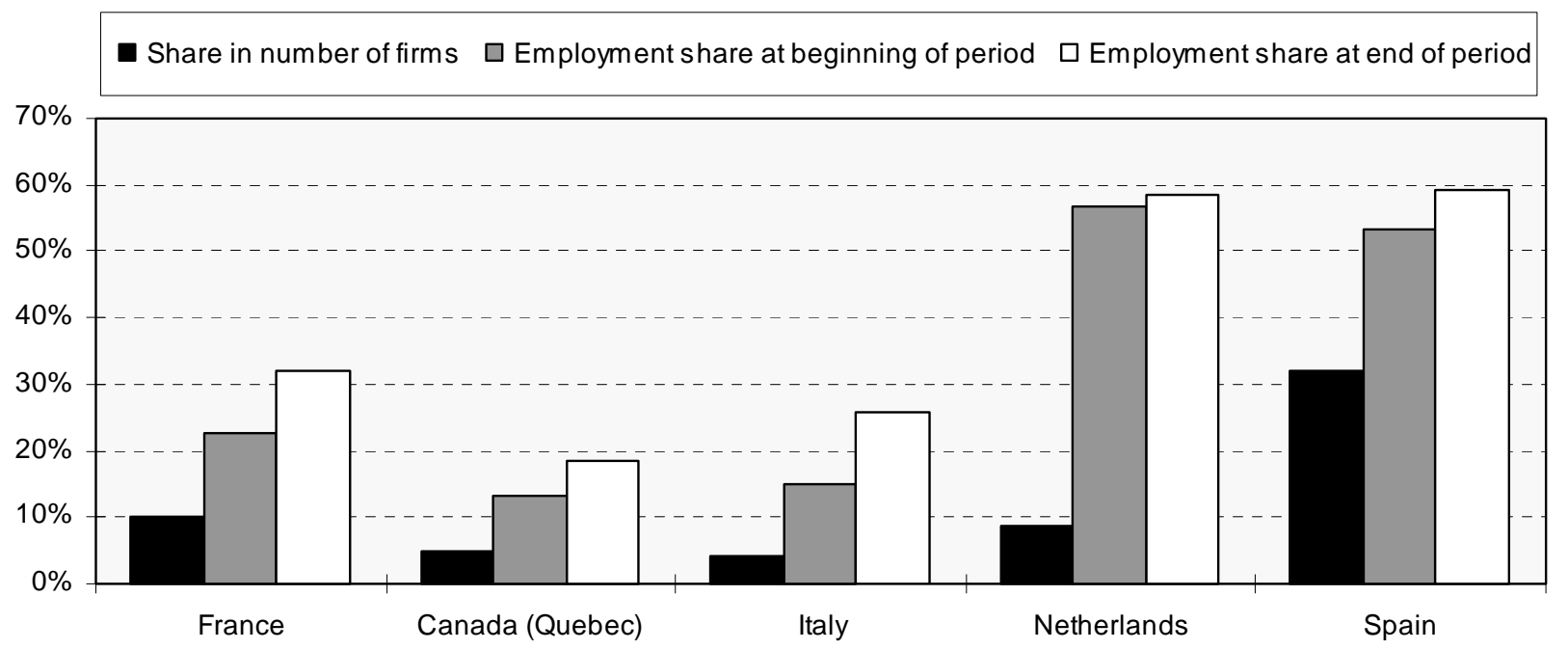

Source: OECD, based on country studies. 
Figure 2 produces similar results but in relation to the set of all growing firms. A marked qualitative difference is observable for Spain: about one-third of all growing firms are qualified as rapidly expanding ones and, unlike in Figure 1, the average size of fast growers exceeds that of all growing firms. The large share of rapidly expanding firms in the set of all growing firms reflects the fact that only about one-third of all firms is actually expanding. This contrasts with other countries, where firm populations are more or less equally divided into growing and shrinking units. One explanation for this difference is simply the macroeconomic situation that Spain faced over the period 1990-94: at the level of the entire economy, employment fell at a rate approaching $2 \%$ per year. It is quite plausible that such a process is marked by a shrinking number of expanding firms. Figure 3 confirms this view as it suggests a positive correlation between macroeconomic employment growth and the share of expanding firms in the samples of the country studies.

What is the contribution of rapidly expanding firms to employment growth? Figure 4 plots the average share of high-growth firms in total employment against the share that these firms occupy in gross job gains. It is immediately apparent that the group of rapidly expanding firms account for a much smaller share in employment than they do in job creation - put differently, high-growth firms exhibit a much stronger propensity to employment generation than the average firm. There are, however, large variations between countries: whereas in France, Italy and the Netherlands, between 50\% and 60\% of employment gains can be associated with high-growth firms, this percentage is significantly smaller in Canada and significantly higher in Spain. Possible explanations include:

- The cyclical position in Spain mentioned earlier, which comes along with a reduction of the share of expanding firms in the total firm population, and pushes a large share of the expanding firms into the top $10 \%$ category of high-growth firms. Consequently, a very large part of gross employment gains are attributed to high-growth firms. One notes also that the Spanish study relates to manufacturing only and so paints the picture of a sector with more severe job losses than other parts of the economy.

- The selection of high-growth firms in Canada, which is based on the top 5\% of all growing firms. Other countries' sets of fast-growing units are either based on the top quintile of all permanent firms (Italy, Netherlands, Spain and Sweden) or on the top 10\% of all growing firms (France). Either way, the implication is a downward bias in the share of high growers for Canada when compared with other countries.

\section{A profile of high-growth firms}

\subsection{Size}

Having established that a large part of job gains are concentrated among rapidly expanding firms, it is of immediate interest to determine the differentiating characteristics of this set of firms. The first characteristic is the size dimension of the contribution of fast growers to employment gains. Figure 5 depicts the average contribution to employment growth. Several observations can be made. First, both small and large firms provide important contributions to overall employment gains - one exception is the Netherlands where by far the largest contribution comes from large firms. Note, however, that the fact that the allocation of Dutch firms to size classes is based on each firm's size at the end of the period biases the international comparison as all other countries use each firm's size at the beginning of the period to allocate size. Second, the role that large firms play in the employment growth of high-growth firms is more important than the role they play in the job gains of growing firms. This emerges clearly from Figure 6 where the share of small and medium-sized firms in employment growth is shown both for the set of growing firms and for the set of fast-growing ones. 
Figure 3. Macroeconomic employment growth and share of expanding firms

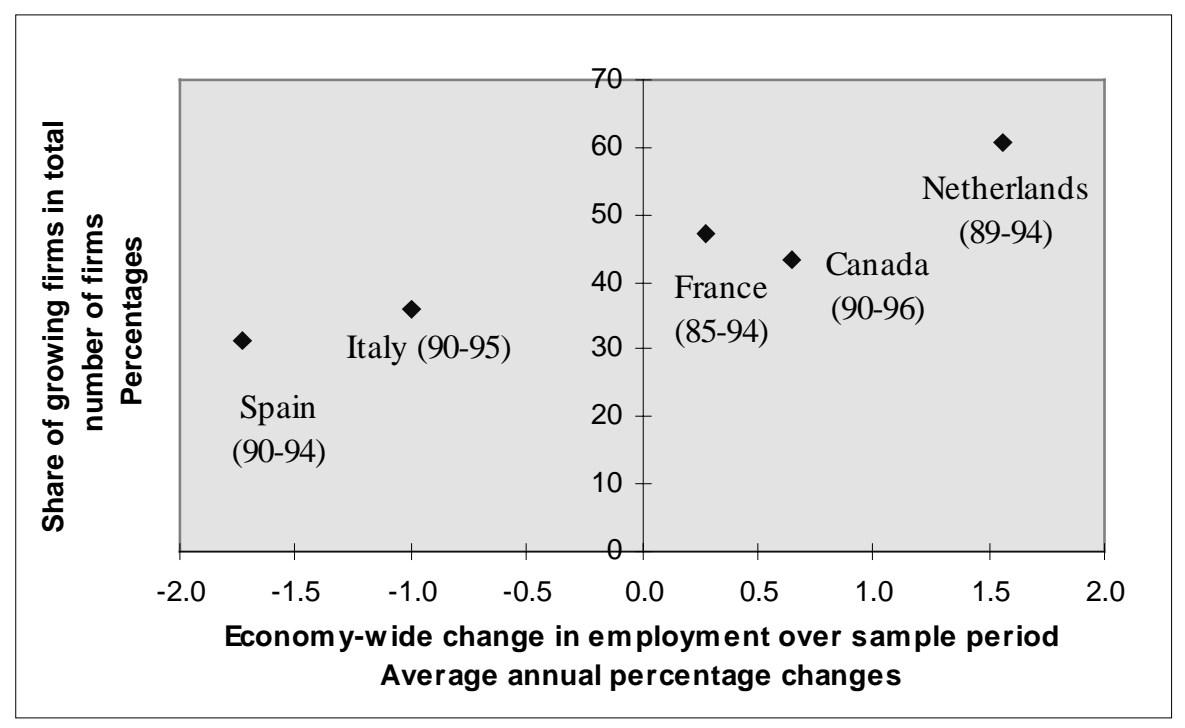

Source: OECD Economic Outlook 64 and country reports.

Figure 4. High-growth firms and their contribution to job gains

\section{Percentages}

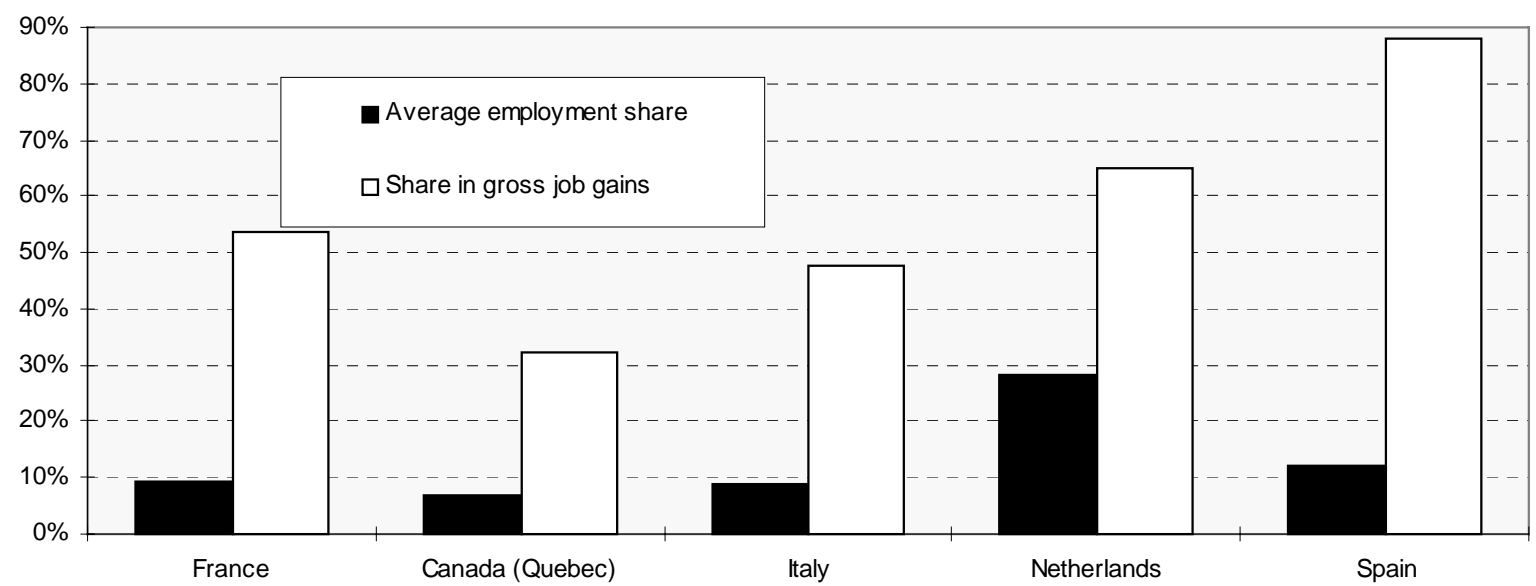

Source: OECD, based on country studies. 
Figure 5. Employment growth of growing and high-growth firms

Contributions by different size classes ${ }^{1}$

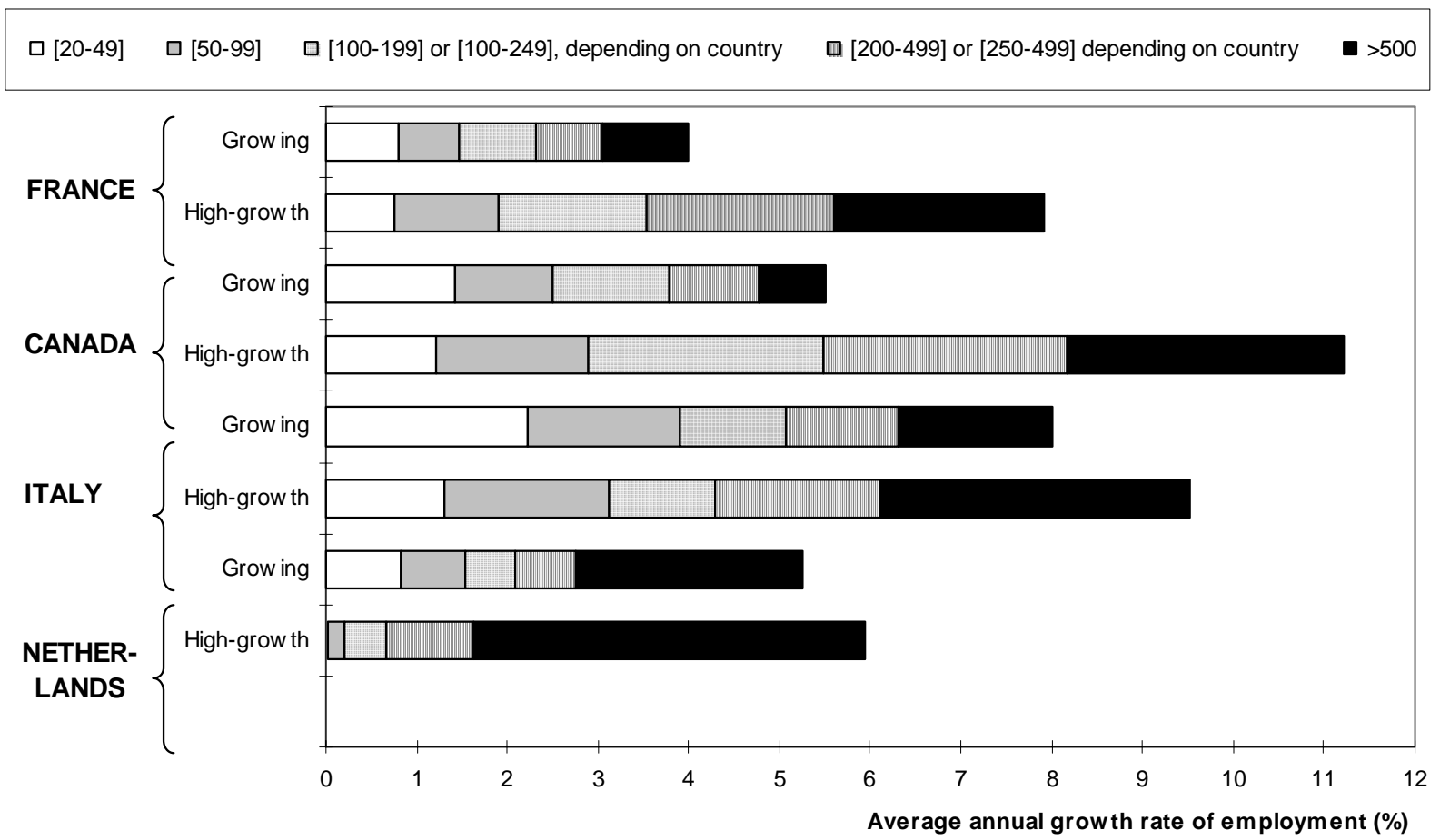

1.Contributions of size classes are calculated as the logarithmic average annual growth rate of employment multiplied by the average weight of each size class in employment between the end and the beginning of the period. Source: OECD based on country reports.

Figure 6. Share of SMEs ${ }^{1}$ in employment growth of growing and high-growth firms

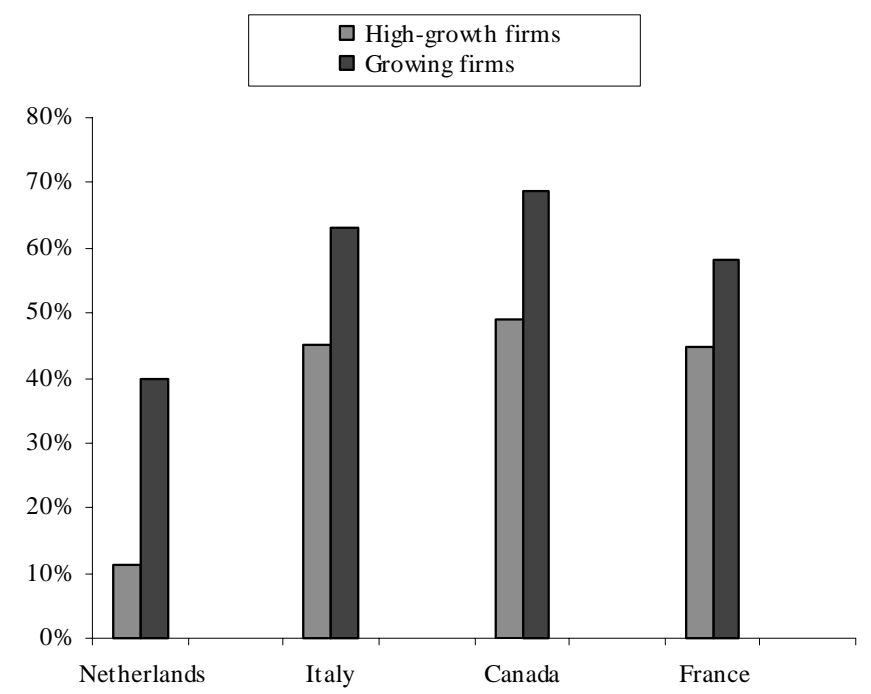

1.Depending on the country, SMEs comprise firms between 20 and 249 or 200 employees. Source: OECD based on country reports. 
In summary then, it appears that large firms play a more important role as employment creators among high-growth firms than they do among growing firms. This is of course directly related to the specific notion of high-growth and the associated growth index, designed to pick up innovative efforts across the economy. However, those small firms that are part of the so defined set of fast growers are exceptional performers when it comes to their propensity to generate jobs.

\subsection{Age}

Another important differentiating characteristic of firms is their age. There is a consensus in the empirical literature about the link between age, size and (proportional) growth: for any given size, the proportional growth rate of firms tends to decline with age. At the same time, older firms have a greater probability of survival than younger ones. Such patterns are consistent, for example, with models of firm selection, in particular Jovanovic (1982), where market entrants take time to learn about their relative efficiency. A selection process takes place and operates with greater intensity during the earlier life cycle of firms. Consequently, young firms are marked by greater volatility of growth patterns than older plants. Those young firms that turn out to be efficient during the initial selection process survive to maturity and settle down to relatively stable employment levels (Davis et al., 1996).

Where age effects were isolated in the present country studies, the relation between growth and age was largely confirmed, and holds also for the combined index of relative and absolute growth:

- The Canadian study tested whether the age of firms had an impact on their probability of being a growing firm. As it turns out, there is a significant and negative relationship that is all the more telling as the Canadian study simultaneously controlled for other effects such as size, or industry, or regional affiliation. It also emerges that the link between age and growth becomes stronger as firm size diminishes. Thus, a firm of 250 employees of a certain age has a greater chance of growing than a larger firm of the same age.

- Similar conclusions arise from the Spanish case study, and are shown in Figure 7. The age group $0-5$ years exhibits the largest share of growing firms, indicating that the probability to grow declines over the life cycle of firms.

- The Dutch study finds that high-growth companies are more likely to be young than low-growth companies. In the study, which covers the period between 1989 and 1994, one-quarter of the high-growth companies was formed after 1980. Low growth companies, on the other hand, were more likely to pre-date 1950 (Ministry of Economic Affairs, 1999).

However, whereas the link between growth and age appears to be robust, the correlation between rapid growth and age is less clear-cut. For example, from the Spanish case (Figure 7) it arises that the probability of being part of the set of high-growth firms does not decline as firm age rises. On the other hand, the Dutch study is a case where young firms account for a larger share of the set of fast-growing firms than they do of the set of all other firms, thus indicating a negative relation between adherence to the fast-growing group and age. The German study also indicates a share of fast-growing firms that falls as age increases, although results differ somewhat between the two datasets employed and regression analysis, which controls for several factors simultaneously, does not detect a clear-cut link between the probability of being a high-growth firm and age. The Swedish study includes entrants over the period of observation, and the authors find that these entrants account for two-thirds of all high-growth firms - a much larger share than the one they occupy on average. The set of high-growth firms is thus dominated by (young) entrants - a population of firms that is not captured by other studies restricted to the set of permanent firms. 
The Swedish study offers yet another, interesting aspect, related to the distinction between "organic" and "total" firm growth. "Organic" growth corresponds to internal, "total" to both internal and external growth of firms. The latter comprises in particular mergers and acquisitions - a phenomenon that occurs almost exclusively among firms of a certain age. In the context of a discussion about firm growth and job creation, the distinction becomes important. If two firms of a certain age merge, and if the measure of firm growth comprises external growth, there will be a statistical occurrence of a high-growth firm. However, no new employment has been generated. Thus, from an employment perspective, an analysis of internal growth only is useful and the Swedish data set permits to do this. There are several important outcomes from the Swedish case:

- First, only about one-third of all employment gains by high-growth firms is internal growth: twothirds of employment gains are in high-growth firms that grew fast as a consequence of mergers and acquisitions.

- Second, when employment gains are restricted to internal growth, the age profile of high-growth firms becomes very accentuated and nearly all of the contribution to employment gains comes from young firms as acquisitions are concentrated among older firms (Figure 9). As the age profile of fast growers and their employment contribution changes, so does the size profile. The $20 \%$ share of high-growth SMEs in total (internal and external) employment growth about doubles if only internal growth is considered.

In summary, three conclusions can be drawn regarding the age profile of growing and fast-growing firms:

- The first conclusion is that the probability of expanding employment declines with the age of firms: the share of growing firms is highest among the young ones.

- Secondly, it seems fair to conclude that a similar relation holds for the set of fast-growing firms: despite counter-examples such as Spain, the evidence points in this direction.

- Thirdly, the Swedish case makes it clear that the balance may tip towards young firms as job creators when only internal employment growth is considered. Similarly, including entrants in the panel increases the share of young firms among the fast growers. Both observations tend to reinforce conclusions one and two as there is little reason to believe that growth through acquisition is concentrated among young firms outside Sweden or that entrants would behave fundamentally different in other countries. 
Figure 7. Spain (1990-94): Share of growing and fast-growing firms by age group Percentages

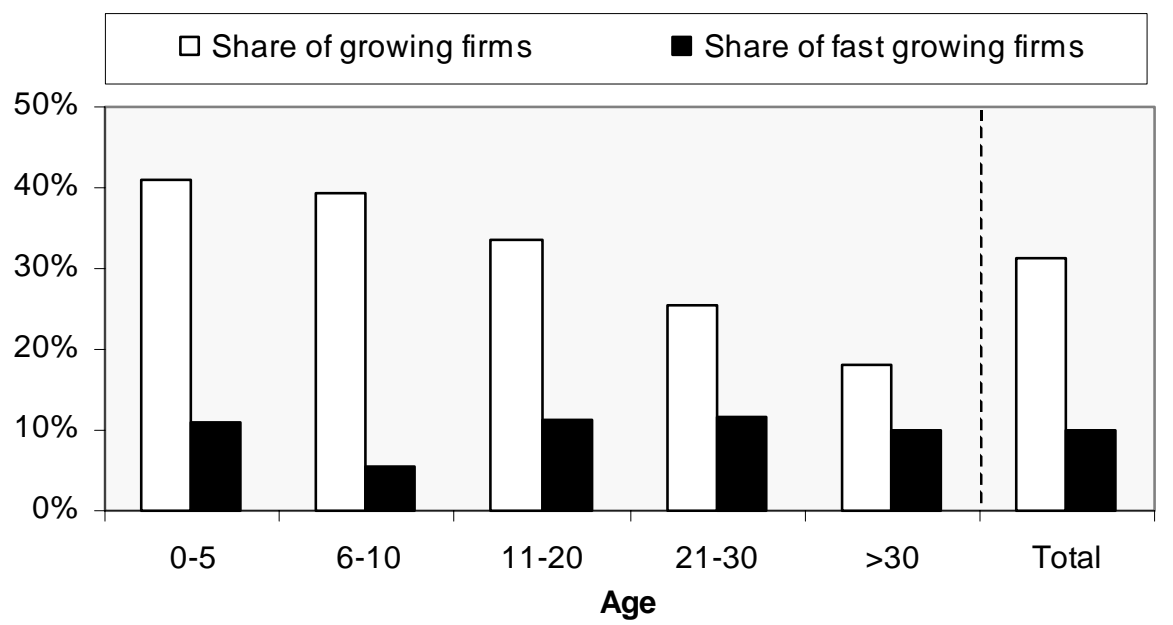

Source: OECD, based on country report.

Figure 8. Germany (1989-95): Share of fast-growing firms by age group

Percentages
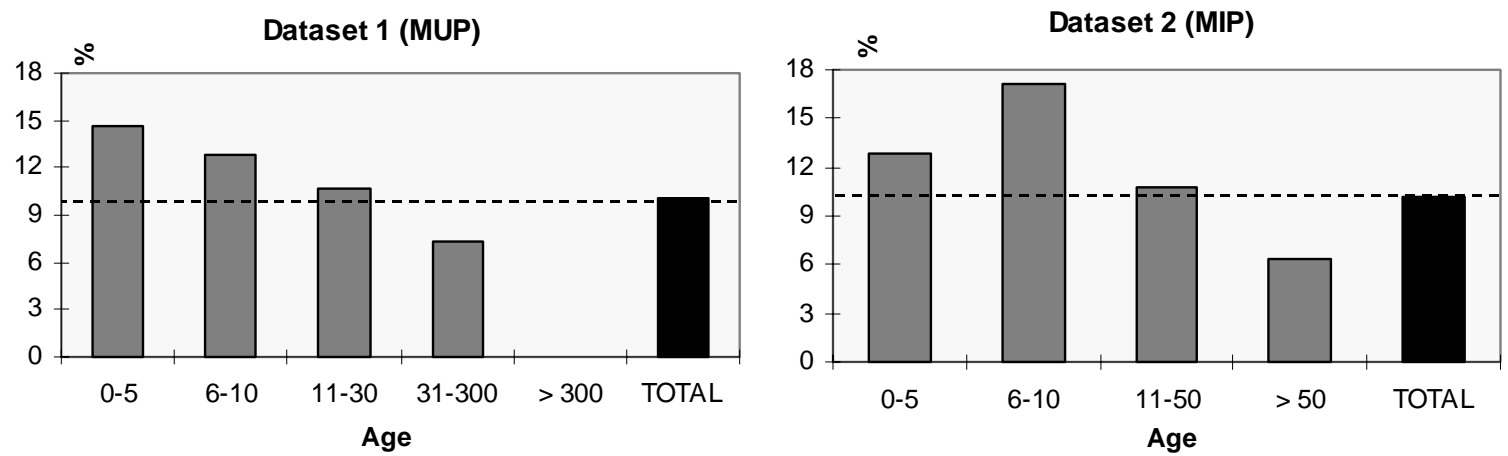

Source: OECD, based on country report. 
Figure 9. Sweden (1987-96): Share of internal growth in total employment growth by age group

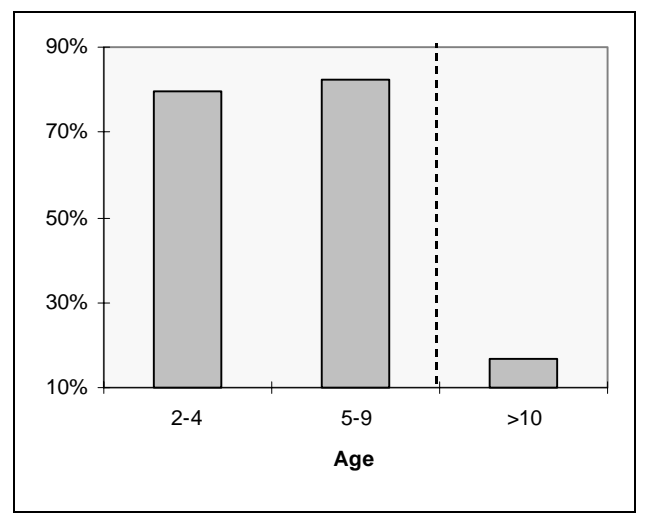

Source: OECD, based on country report.

\subsection{Economic activity}

Are high-growth firms to be found in specific industries or is there no discernible pattern of a predominant economic activity? As with other characteristics, general statements are hampered by the differences in the sectoral coverage of the country studies. In analytical terms, a distinction must be drawn between two measures: $a$ ) the share of an industry in the total number of high-growth firms; and $b$ ) the distribution of high-growth firms within industries. Measure $a$ ) provides an indication about the overall concentration of high-growth firms in a particular industry without, however, controlling for the size of the sector. Measure $b$ ) indicates the share of high-growth firms, while controlling for industry size. Consequently, significant industry concentration according to measure $a$ ) is perfectly compatible with a uniform distribution of measure $b$ ), when industries are of different size.

The following observations all relate to measure $b$ ). Those country case studies which cover the entire economy and differentiate by economic activity, such as Sweden, tend to find that high-growth firms exist in all industries but that they are relatively more frequent in knowledge-intensive service industries and in education and health care. Similarly, the Dutch study found no significant differences in the frequencies at which high-growth firms exist in various industries, with the exception of business services where highgrowth firms account for $18 \%$ of all firms compared to $9 \%$ for the industry average. A similar picture emerges from the Canadian study, which relates only to the manufacturing industry but offers a greater level of disaggregation. With the exception of the transport equipment producing industry, industry effects are hardly discernible in terms of the share of fast growers in the overall number of firms. Nor is there a disproportionate contribution to employment growth by any one industry's high-growth firms. In France, high-growth firms appear relatively more often in the pharmaceutical, electronics and rubber industries than elsewhere. The German study finds that the probability of belonging to the set of fast-growers is significantly higher in the services than in manufacturing. In the sample of the Spanish manufacturing industry, high-growth firms are over-represented in the chemicals, electronics and rubber and plastics industries.

Statistically, the degree of industry concentration based on measure a) can be synthesised by a coefficient of variation, as presented in Table 3. It shows that there is a greater dispersion of fast-growing 
firms than of growing ones. Also, a simple correlation between the industry measures for growing and fastgrowing firms shows that the link is weak - an industry with an above-average share of growing firms does not necessarily also exhibit an above-average share of fast-growing firms. Thus, fast-growing firms tend to be more concentrated in some sectors as opposed to growing firms but the concentration is not necessarily in the same industries.

Table 1. Growing and high-growth firms by industry

\begin{tabular}{|c|c|c|c|c|c|c|}
\hline \multirow[t]{2}{*}{ Country } & \multicolumn{2}{|c|}{$\begin{array}{c}\text { Share of growing firms in each } \\
\text { industry }\end{array}$} & \multicolumn{2}{|c|}{$\begin{array}{c}\text { Share of high growth firms in each } \\
\text { industry }^{2}\end{array}$} & \multirow{2}{*}{$\begin{array}{c}\text { Share of growing and } \\
\text { share of high growth } \\
\text { firms }^{3}\end{array}$} & \multirow{2}{*}{$\begin{array}{c}\begin{array}{c}\text { Industry shares in } \\
\text { growing and high- } \\
\text { growth firms }\end{array} \\
\begin{array}{c}\text { Coefficient of } \\
\text { correlation }\end{array}\end{array}$} \\
\hline & $\begin{array}{c}\text { Unweighted } \\
\text { average across } \\
\text { industries (\%) }\end{array}$ & $\begin{array}{c}\text { Coefficient of } \\
\text { variation }{ }^{5} \text { across } \\
\text { industries }\end{array}$ & $\begin{array}{c}\text { Unweighted } \\
\text { average across } \\
\text { industries (\%) }\end{array}$ & $\begin{array}{c}\text { Coefficient of } \\
\text { variation across } \\
\text { industries }\end{array}$ & & \\
\hline France & 47.3 & 1.5 & 4.9 & 2.5 & 0.76 & 0.68 \\
\hline Canada & 44.7 & 1.2 & 2.6 & 1.7 & 0.42 & 0.63 \\
\hline Italy & 35.7 & 2.0 & 1.8 & 1.5 & -0.28 & 0.91 \\
\hline Netherlands & 61.2 & 0.7 & 5.8 & 3.6 & 0.71 & 0.91 \\
\hline Spain & 29.9 & 2.6 & 8.3 & 3.8 & 0.22 & 0.93 \\
\hline
\end{tabular}

1. Based on column B in Annex Tables 1-5.

2. Based on column $\mathrm{C}$ in Annex Tables 1-5.

3. Coefficient of correlation between columns $D$ and $E$ in Annex Tables 1-5.

4. Coefficient of correlation between columns B and C in Annex Tables 1-5.

5. Standard deviation divided by mean.

Source: OECD, based on country reports.

\subsection{Regional dimension}

There is a double interest in the regional dimension of high-growth firms. From an employment policy perspective, the regional dimension can be of interest if employment gains are, for example, highly concentrated in one area. From a technology and industry policy perspective, the regional aspect of highgrowth firms is closely linked to the notion of industrial clusters - networks of firms that feature a high degree of specialisation and tend to benefit from spillovers through geographical proximity. Well-known examples of such clusters include high-tech areas such as Silicon Valley in the United States or the textile industry in Northern Italy.

Akin to the industry dimension, it emerges from the country studies that high-growth firms exist throughout national territories. But there is a small number of regions that stand out with a much higher share of fast-growing firms than their share in the overall number of firms would suggest. Such results hold for Spain, for Germany ${ }^{10}$ (showing a premium on urban areas) and for France (one-third of all high-growth firms are found in the Paris region, which accounts for only one-quarter of all permanent firms in the sample). In other words, the occurrence of high-growth firms is roughly in proportion to the overall occurrence of firms across regions, with one or two exceptions per country. One notes that this does not exclude a strong regional concentration of high-growth firms but such concentration comes along with a generally intense economic activity in the same region. What the observation suggests, however, is that it is unlikely to find high-growth firms in areas that are otherwise not centres of economic activity. ${ }^{11}$ 


\subsection{Dependence and independence}

The distinction between independent firms and those that are partly or wholly owned by others, is of interest in the context of job creation. It has been the object of earlier research, notably in France (Boccara, 1997) where it was found that dependent SMEs were more important in creating additional employment than independent firms. Such a finding sheds light on the role of network effects and the effects of shared resources between parent firms and their affiliates.

In the Swedish country report, dependent firms turn out to be somewhat over-represented among the high-growth group, based on a panel of permanent firms (Figure 10). More or less the same picture emerges for Canada, the Netherlands and Spain. France also features a large share of dependent firms in the high-growth group but no comparison exists with the overall panel. Overall, it would occur that dependent firms play a more-than proportional part in the dynamic group of high-growers. This is a plausible finding:

- Financing has frequently been cited as an important constraint to expansion. Given that dependency rises with equity financing, a strong presence of dependent firms among fast growers is not surprising.

- Access to human capital, another important factor in firm growth and innovation, would appear to be facilitated within groups of dependent firms, if recruitment, training and mobility involve fixed costs or minimum size and/or if groups benefit from the wage premium that is typically observed with large firms.

- Access to information about markets, products and technologies is likely to be facilitated in groups.

An important qualification applies, nonetheless: as shown in the Swedish study, the discrepancy between dependent and independent firms vanishes when new entrants are considered in the panel. New firms are mainly independent, and at the same time well represented in the high-growth group. Consequently, the inclusion of young firms raises the share of independent units among the set of fast growers.

The overall message is somewhat more differentiated when it comes to the roles of dependent and independent firms in job creation. In Sweden and Canada, dependent firms account for a relatively larger part of job creation in the high-growth segment than they do in the overall panels of firms, an observation that does not hold for the Netherlands where independent firms are over-represented as high-growth job creators. The Dutch study points also to another issue, namely that the distinction between dependent and independent firms relies on a formal financial criterion - typically, a firm is considered dependent if at least $51 \%$ of it are owned by another unit. However, according to the findings for the Netherlands, highgrowth firms are specifically prone to engage in informal alliances, especially when they are small.

Yet another aspect is brought out by the German country report, which investigates the relationship between the liability status of firms and the probability to be part of the high-growth set. As to be expected, the results indicate that corporate status has a significant and positive effect on the likelihood to be a fast grower. This does not answer the question of causality - does the corporate status encourage firms to be more entrepreneurial or are fast growers corporate firms because this offers a natural way to finance expansion? Whichever direction the causality works, it certainly shows the importance of economic and legal institutions that govern access to and responsibilities for firms under corporate status. 
In summary, then, there is a strong presumption that high-growth firms do not operate in an isolated manner. Their integration into networks - be they financial ones or informal alliances - appear to be one of their outstanding characteristics.

Figure 10. Share of dependent firms

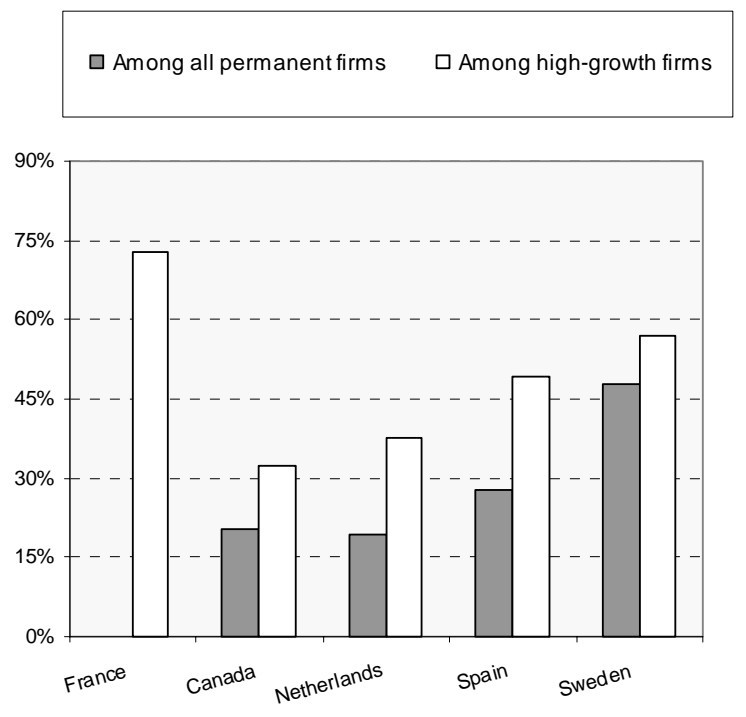

Source: OECD, based on country reports.

\section{6. $R \& D$ and innovation}

In light of the interpretation of high-growth firms as innovators that was given earlier on, evidence on the link between $R \& D$ and the occurrence of fast growth is of particular interest. As with other differentiating characteristics, coverage of the topic remains scattered across the country studies. Nonetheless, all the existing evidence points in the same direction: high-growth firms are more technology intensive than the average firm:

- The Spanish study compares the distribution of all firms, growing firms and high-growth firms by R\&D intensity. About half of the overall population of firms undertakes R\&D, but more than $70 \%$ of the high-growth group does. Moreover, for given R\&D intensities, the high-growth group always comes out as the one with the highest share of R\&D firms (Figure 11). Thus, high-growth units are more technology intensive than firms on average or than growing firms. 
Figure 11. Spain: R\&D intensity by type of firm

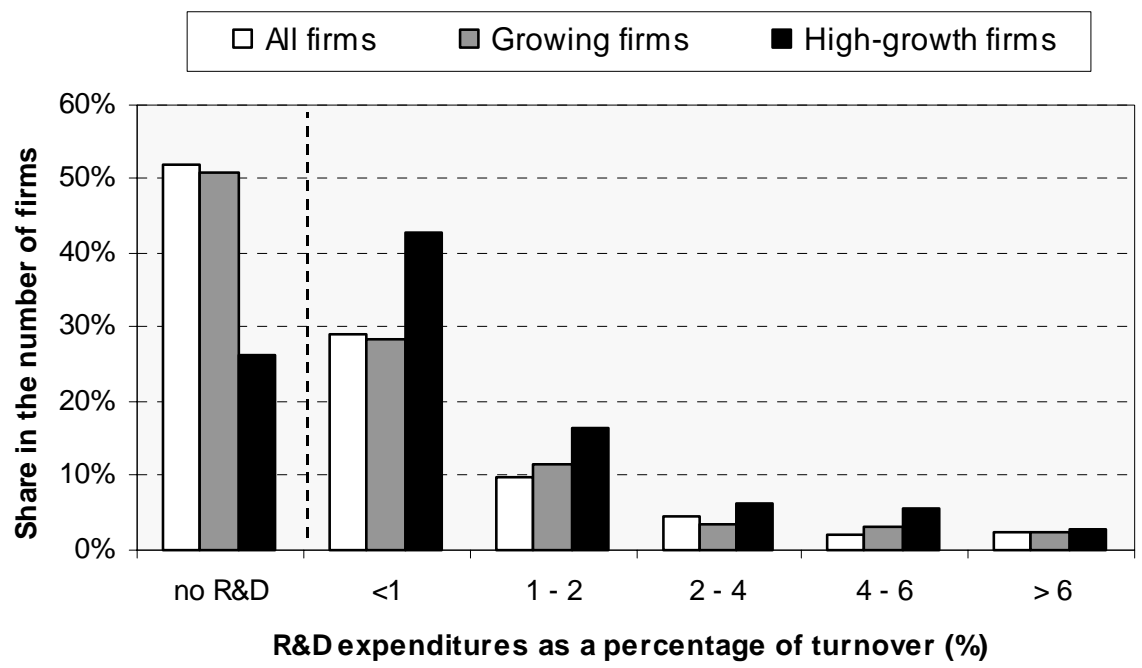

Source: OECD, based on country report.

Figure 12. Germany: share of firms in high-growth group by R\&D intensity Percentages

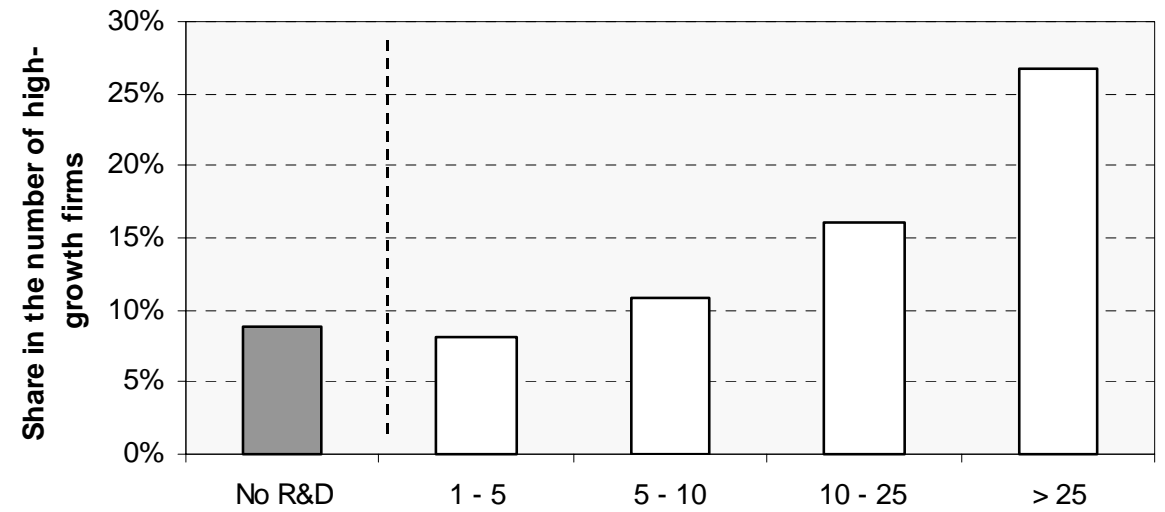

R\&D personnel as a percentage of total employees (\%)

Source: OECD, based on country report. 
- The German panel data set yields similar results, although in a somewhat different presentation. From Figure 12 it is apparent that the share of firms that qualify as high-growers rises with the intensity of R\&D activity.

- The French country study reports that $13 \%$ of all firms in the sample carry out formal R\&D efforts. This contrasts with a figure of $33 \%$ for the group of fast growers - nearly three times as high.

- Lastly, the results from the Dutch study point in the same direction: high-growth firms focus more frequently than other firms on product and market innovation and devote considerable attention to the positioning of their products and product lines (Ministry of Economic Affairs, 1999).

\section{Main findings and some policy implications}

Structural unemployment and weak employment growth have marked labour market developments in many OECD countries. One of the more general factors that determines countries' employment growth record and labour market performance is the economies' capacity to adapt to change. Governments can influence this capacity but the actual implementation of change rests with private agents. Some of the most important agents of change are entrepreneurs - individuals with the capacity and willingness to take risks, to be innovative and to exploit business opportunities in a market environment.

Where the expansion and contraction of firms has been tracked empirically, a common observation has been a picture of significant variance in growth and job creation performance of firms, even if they operate in the same, narrowly defined market. Specifically, it has been noted that there is often a small group of firms that are responsible for a large share of new jobs created.

The present work deals with this group of rapidly expanding firms. It does so by placing the discussion into a context of entrepreneurship, arguing that there are two main aspects to this notion: one of business start-ups and market entry, and another one of innovation. Both aspects are current in the literature and provide plausible characterisations of entrepreneurship. In the present report, then, rapid growth is understood as entrepreneurial success with a focus on the innovation aspect. ${ }^{12}$

Evidence is based on results from five OECD countries (Germany, Italy, Netherlands, Spain and Sweden) as well as from Quebec (Canada). Each of these studies used a firm-level data set to identify highgrowth firms and their differentiating characteristics. Despite considerable differences in the underlying data and some of the methodologies, a number of common findings emerge.

\subsection{Main findings}

These findings can be summarised as follows:

a) Small firms exhibit higher net job creation rates than large firms do. At the same time, significant flows of gross job gains co-exist with large flows of gross job losses, especially among small firms. Both observations are in line with many earlier studies on the topic. 
b) High-growth firms account for a disproportionately large part of gross jobs gained. High-growth firms are those firms that rank first according to a measure that combines relative (percentage) and absolute rates of employment expansion.

c) Among high-growth firms, job creation rates of small firms exceed those of large ones.

d) In absolute terms, larger firms are also significant job creators in the high-growth group. Specifically, they play a more important role as employment creators among high-growth firms than they do among growing firms. On the other hand, the rapid growth of large firms often reflects mergers and acquisitions rather than internal growth. This puts a question mark on the extent at which genuinely new jobs created by these units.

e) High-growth firms are found in all industries and in all regions of the countries examined. Fastgrowing firms tend to be more concentrated in some sectors as opposed to growing firms but the concentration is not necessarily in the same industries.

f) High-growth firms are more $\mathrm{R} \& \mathrm{D}$ intensive than growing firms or than the average permanent firm.

g) Firms that are partly or wholly owned by others tend to be more than proportionally represented among the set of fast growers. More partial evidence shows also that fast-growing units are more often involved in alliances than the average firm.

h) Growing firms tend to be younger than firms on average. There is partial evidence (Swedish case study) that job gains by new entrants match those by permanent firms and it is likely that similar findings would hold for other countries.

\subsection{Link to entrepreneurship}

It would appear that these results fit together in a conceptual framework centred on entrepreneurship. Because entrepreneurship implies uncertainty and asymmetric distribution of information, it is an idiosyncratic, search-oriented process. Finding $a$ ), which reflects considerable heterogeneity among firms, is consistent with this view. It has been argued earlier on that two aspects of entrepreneurship can usefully be distinguished: one that focuses on firm entry, start-ups, and exit in industries. The other aspect, dealt with in the present document, is innovation. Because it is difficult to establish a general link between innovation and firm size, high-growth firms were chosen on criteria that do not a priori favour a particular size class. The resulting set of high-growth firms comprises therefore both large and small firms, as pointed out in finding $d$ ). There is a clear positive link between the R\&D efforts and the emergence of high-growth (finding $f$ )). This lends additional support to the idea that a search process is observed and that it is reasonable to think of the set of high-growth firms as successful entrepreneurs.

Finding $h$ ) on the significance of young age stands out, as it holds for samples of permanent firms with minimum size, thus excluding very small (and very young) firms as well as entrants. Hence, even among permanent firms of a certain maturity, younger firms tend to be relatively more successful in moving towards an expansion path. The age component becomes even more important when entrants are included in the analysis or when employment growth measures are restricted to internal growth, excluding mergers and acquisitions. 


\subsection{Some policy implications}

The above findings and their interpretation in a context of entrepreneurship give rise to several, preliminary policy implications:

If exceptional growth is associated with entrepreneurial activity and if idiosyncratic knowledge, asymmetric information and risk mark the latter, there is little reason to believe that governments have superior knowledge about markets, technologies and projects compared to the individual entrepreneur. It is thus difficult to define specific criteria for selecting firms, industries or regions eligible for government support. There is no simple or mono-causal explanation for fast growth or the absence thereof. Generally, the present study has again provided evidence of the considerable heterogeneity among firms (high-growth or other) which makes any kind of policy that is linked to "common characteristics" hard to formulate and implement.

What follows for policy is the importance of supporting the functioning of the search process, through appropriate institutional, legal and administrative framework conditions. If specific action is taken in support of firms, it should be to help them to find out about the viability of their goods and services but not to help them with the goods and services themselves. ${ }^{13}$ Policies with "framework" character are of fundamental importance - their main focus lies in fostering the working of markets and in removing unnecessary obstacles to the creation, expansion, development and exit of firms.

One such policy area is linked to the documented relation between age and the emergence of growing firms. It points to the importance for governments to review policies and framework conditions that have a bearing on firm expansion at early stages of the life cycle of firms and to complement those policies that are size-related. Examples include: $i$ ) measures to facilitate financing of business expansion such as taxation favouring or inhibiting business angels and venture capital, or the possibility to issue stock options; $i$ ) rules and regulations that influence the cost of hiring the first employee [see OECD (1998a) for evidence]; iii) the protection of intellectual property rights for young, innovative firms; $i v$ ) administrative impediments to setting up firms (e.g. the time and expenses involved in registering a new business) and other economic incentives such as the consequences of exiting and business failure.

It should be noted that such policies directed at young firms come as a complement to policies directed at small firms - and not necessarily as a replacement of the latter. Some SME policies try to compensate for the fact that many "mainstream policies", e.g. labour market regulations, social security laws, taxation etc. have been designed with an image of large firms in mind, and sometimes disadvantage small business.

It has also been argued that chances for entrepreneurial success rise with the existence of a flexible and educated work force. This plays twofold. First, skilled labour shortages have been quoted as important impediments to the expansion of small and young firms. Policy recommendations remain broad in this case and relate to education and support of lifelong learning. Second, well-educated persons are more likely to start a new business than others are and so provide a pool of potential entrepreneurs. Thus, it is also important to facilitate the emergence and maintenance of high-quality educational institutions to ensure a steady supply of highly qualified persons and potential entrepreneurs. 


\section{REFERENCES}

Audretsch, David B. (1995), Innovation and Industry Evolution, MIT Press.

Birch, David (1981), "Who Creates Jobs?”, The Public Interest 65.

Baljé, Sander H. and Pieter M. Waasdorp (1999), "Fast-growing Enterprises: Discoverers and Innovators", in Ministry of Economic Affairs (1999), Entrepreneurship in the Netherlands.

Boccara, Frédéric (1997), "Mythes et réalités sur l'emploi et la croissance des PME : le rôle des groupes (1984-1992)", Document de travail, INSEE.

Boeri, Tito (1994), “Why are Establishments so Heterogeneous?”, Small Business Economics 6.

Caballero, Ricardo, M. Eduardo, R.A. Engel and John Haltiwanger (1997), "Aggregate Employment Dynamics: Building from Microeconomic Evidence", American Economic Review, March.

Carree, Martin and Luuk Klomp (1996), "Small Business and Job Creation: A Comment", Small Business Economics 8.

Caves, Richard (1998), "Industrial Organization and New Findings on the Turnover and Mobility of Firms", Journal of Economic Literature.

Cohen, Wesley (1995), "Empirical Studies of Innovative Activity”, in Paul Stoneman (ed.), Handbook of the Economics of Innovation and Technological Change.

Cohen, Wesley M. and Richard C. Levin (1989), "Empirical Studies of Innovation and Market Structure", in Richard Schmalensee and Robert D. Willig (eds.), Handbook of Industrial Organisation.

Davidsson, Per, Leif Lindmark and Christer Olofsson (1998), "The Extent of Overestimation of Small Firm Job Creation - An Empirical Examination of the Regression Bias", Small Business Economics 11.

Davidsson, Per, Leif Lindmark and Christer Olofsson (1995), "Smallness, Newness and Regional Development", paper presented at the OECD High-level Workshop on SMEs, Innovation and Employment, Washington DC.

Davis, Steven, John C. Haltiwanger and Scott Schuh (1996), Job Creation and Destruction, MIT Press.

Dunne, Timothy, Mark J. Roberts and Larry Samuelson (1989), "Patterns of Firm Entry and Exit in U.S. Manufacturing Industries", Rand Journal of Economics.

Evans, David S. (1987), "The Relationship between Firm Growth, Size and Age: Estimates for 100 Manufacturing Industries", Journal of Industrial Economics. 
Geroski, Paul A. (1995), "What do we Know about Entry?", International Journal of Industrial Organization.

Harhoff, Dietmar, Konrad Stahl and Michael Woywode (1998), "Legal Form, Growth and Exit of West German firms - Empirical Results for Manufacturing, Construction, Trade and Service Industries", The Journal of Industrial Economics.

Kirzner, Israel (1997), "Entrepreneurial Discovery and the Competitive Market Process: An Austrian Approach", Journal of Economic Literature, Vol. XXXV.

Ministry of Economic Affairs of the Netherlands (1999), High-growth Companies in the Netherlands.

OECD (1994a), The OECD Jobs Study, Paris.

OECD (1994b), OECD Employment Outlook, Paris.

OECD (1996a), Technology, Productivity and Job Creation, OECD, Paris.

OECD (1996b), OECD Employment Outlook, OECD, Paris.

OECD (1997a), Implementing the OECD Jobs Strategy: Member countries' Experience, OECD, Paris.

OECD (1997b), Small Business, Job Creation and Growth: Facts, Obstacles and Best Practices, OECD. Paris.

OECD (1998a), Fostering Entrepreneurship, OECD, Paris.

OECD (1998b), Technology, Productivity and Job Creation: Best Policy Practices, OECD, Paris.

Picot, G., J. Baldwin and R. Dupuy (1994), "Have Small Firms Created a Disproportionate Share of New Jobs in Canada? A Reassessment of the Facts", paper presented at the Canadian Economics Association Meeting, June, Calgary.

Stoneman, Paul (1996), "Introduction" in Paul Stoneman (ed.), Handbook of the Economics of Innovation and Technological Change.

Storey, David (1997), The Ten Percenters, London, Deloittle \& Touche.

Sutton, John (1995), "The Size Distribution of Businesses, Part I", STICERD Discussion Paper No. EI/9, London School of Economics.

Sutton, John (1997), “Gibrat's Legacy”, Journal of Economic Literature, Vol. XXXV.

Symeonidis, George (1996), "Innovation, Firm Size and Market Structure: Schumpeterian Hypothesis and Some New Themes", OECD Economic Studies.

Wagner (1995), "Talkin' 'bout Job Generation: Firm Size and Job Creation in Germany”, University of Lüneburg Working Papers No. 143. 


\section{ANNEX TABLES}

Annex Table 1. France: growing and high-growth firms by industry Percentages

\begin{tabular}{|c|c|c|c|c|c|}
\hline & \multicolumn{3}{|c|}{ Distribution across sectors } & \multicolumn{2}{|c|}{ Distribution within sectors } \\
\hline & All firms & Growing firms & $\begin{array}{l}\text { High-growth } \\
\text { firms }\end{array}$ & $\begin{array}{c}\text { Growing firms } \\
\text { as share of all } \\
\text { firms }\end{array}$ & $\begin{array}{c}\text { High-growth } \\
\text { firms as share } \\
\text { of all firms }\end{array}$ \\
\hline & A & $\mathrm{B}$ & $\mathrm{C}$ & $\mathrm{D}$ & $\mathrm{E}$ \\
\hline Textiles and wearing apparel & 13.2 & 10.0 & 6.2 & 35.8 & 2.2 \\
\hline Leather and footwear & 2.7 & 2.0 & 1.8 & 33.9 & 3.1 \\
\hline Wood and wood products & 2.9 & 3.2 & 1.8 & 51.8 & 2.9 \\
\hline Paper and paper products ; publishing and printing & 11.7 & 12.3 & 8.4 & 49.7 & 3.4 \\
\hline Coke, refined petroleum products and nuclear fuel & 0.3 & 0.2 & 0.0 & 34.5 & 0.0 \\
\hline Chemicals industry & 6.1 & 7.4 & 17.2 & 57.5 & 13.3 \\
\hline Rubber and plastics products & 5.9 & 7.7 & 11.6 & 61.8 & 9.2 \\
\hline Other non-metallic mineral products & 4.5 & 4.6 & 3.8 & 48.8 & 4.0 \\
\hline Basic metals and fabricated metal products & 21.5 & 21.4 & 12.6 & 46.8 & 2.7 \\
\hline Machinery and equipment & 10.4 & 9.5 & 7.4 & 43.1 & 3.3 \\
\hline Electrical machinery and apparatus & 8.5 & 9.1 & 15.0 & 50.7 & 8.3 \\
\hline Transport equipment & 4.1 & 4.3 & 7.4 & 49.9 & 8.5 \\
\hline Other manufacturing industries & 5.7 & 5.6 & 5.0 & 46.2 & 4.1 \\
\hline Mining and quarrying & 2.0 & 1.7 & 0.8 & 41.9 & 1.9 \\
\hline Electricity, gas, and water supply & 0.7 & 0.9 & 1.0 & 56.6 & 6.6 \\
\hline TOTAL & 100 & 100 & 100 & 47.1 & 4.7 \\
\hline
\end{tabular}

Source: OECD, based on country reports. 
Annex Table 2. Canada: growing and high-growth firms by industry Percentages

\begin{tabular}{|c|c|c|c|c|c|}
\hline & \multicolumn{3}{|c|}{ Distribution across sectors } & \multicolumn{2}{|c|}{ Distribution within sectors } \\
\hline & All firms & Growing firms & $\begin{array}{l}\text { High-growth } \\
\text { firms }\end{array}$ & $\begin{array}{c}\text { Growing firms } \\
\text { as share of all } \\
\text { firms }\end{array}$ & $\begin{array}{l}\text { High-growth } \\
\text { firms as share } \\
\text { of all firms }\end{array}$ \\
\hline & $\mathrm{A}$ & $\mathrm{B}$ & $\mathrm{C}$ & $\mathrm{D}$ & $E$ \\
\hline Food processing & 9.4 & 9.2 & 9.2 & 42.7 & 2.2 \\
\hline Beverages & 1.1 & 1.1 & 1.5 & 43.8 & 3.1 \\
\hline Tobacco & 0.2 & 0.2 & 0.0 & 40.0 & 0.0 \\
\hline Rubber & 0.7 & 0.9 & 1.5 & 52.4 & 4.8 \\
\hline Plastics & 4.7 & 6.5 & 4.6 & 60.0 & 2.1 \\
\hline Leather & 1.5 & 1.8 & 1.5 & 50.0 & 2.2 \\
\hline Textile process. & 1.7 & 1.8 & 1.5 & 46.0 & 2.0 \\
\hline Textiles & 3.2 & 3.7 & 6.2 & 50.0 & 4.2 \\
\hline Clothing & 11.9 & 9.9 & 10.8 & 35.9 & 2.0 \\
\hline Wood & 9.9 & 10.1 & 6.2 & 44.1 & 1.4 \\
\hline Furniture & 4.4 & 4.4 & 4.6 & 43.8 & 2.3 \\
\hline Paper & 4.2 & 3.6 & 6.2 & 36.8 & 3.2 \\
\hline Printing & 5.9 & 5.2 & 3.1 & 37.9 & 1.1 \\
\hline Metal processing & 2.2 & 2.4 & 1.5 & 48.4 & 1.6 \\
\hline Metal products & 13.8 & 13.0 & 6.2 & 40.8 & 1.0 \\
\hline Machine making & 4.5 & 5.2 & 4.6 & 49.6 & 2.2 \\
\hline Transport equip. & 2.5 & 3.1 & 12.3 & 53.3 & 10.7 \\
\hline Electric./electronics & 4.4 & 4.4 & 4.6 & 43.2 & 2.3 \\
\hline Mining & 4.2 & 2.9 & 1.5 & 29.6 & 0.8 \\
\hline Petroleum & 1.1 & 0.9 & 1.5 & 34.4 & 3.1 \\
\hline Chemicals & 4.0 & 4.1 & 4.6 & 44.5 & 2.5 \\
\hline Misc. industries & 4.4 & 5.7 & 6.2 & 55.3 & 3.0 \\
\hline TOTAL & 100.0 & 100.0 & 100.0 & 43.3 & 2.2 \\
\hline
\end{tabular}

Source: OECD, based on country reports. 
Annex Table 3. Italy: growing and high-growth firms by industry Percentages

\begin{tabular}{|c|c|c|c|c|c|}
\hline & \multicolumn{3}{|c|}{ Distribution across sectors } & \multicolumn{2}{|c|}{ Distribution within sectors } \\
\hline & All firms & Growing firms & $\begin{array}{l}\text { High-growth } \\
\text { firms }\end{array}$ & $\begin{array}{c}\text { Growing firms } \\
\text { as share of all } \\
\text { firms }\end{array}$ & $\begin{array}{l}\text { High-growth } \\
\text { firms as share } \\
\text { of all firms }\end{array}$ \\
\hline & $\mathrm{A}$ & $\mathrm{B}$ & $\mathrm{C}$ & $\mathrm{D}$ & $E$ \\
\hline Food \& Beverages & 5.8 & 5.7 & 4.9 & 35.3 & 1.2 \\
\hline Tobacco & 0.0 & 0.0 & 0.2 & 15.4 & 7.7 \\
\hline Textiles & 8.5 & 7.4 & 5.9 & 31.2 & 1.0 \\
\hline Wearing apparel & 7.3 & 5.4 & 2.0 & 26.5 & 0.4 \\
\hline Leather \& footwear & 5.3 & 5.1 & 2.7 & 34.7 & 0.7 \\
\hline Wood \& wood prod. & 2.4 & 2.1 & 0.5 & 31.8 & 0.3 \\
\hline Paper & 1.7 & 2.0 & 1.5 & 42.4 & 1.2 \\
\hline Printing & 3.4 & 2.7 & 2.2 & 28.1 & 0.9 \\
\hline Coke, refined petroleum \& nuclear & 0.3 & 0.2 & 0.5 & 24.4 & 2.6 \\
\hline Chemicals ind. & 2.9 & 3.6 & 3.9 & 44.2 & 1.9 \\
\hline Rubber \& plastics & 4.2 & 5.6 & 5.1 & 48.6 & 1.7 \\
\hline Other non-metal. mineral products & 5.8 & 5.0 & 4.6 & 31.0 & 1.1 \\
\hline Basic metals & 2.3 & 2.6 & 1.2 & 40.0 & 0.7 \\
\hline Metal products & 12.8 & 13.7 & 9.0 & 38.6 & 1.0 \\
\hline Machinery and equipment & 11.4 & 12.8 & 10.5 & 40.3 & 1.3 \\
\hline Office machinery \& computers & 0.3 & 0.2 & 0.5 & 30.1 & 2.7 \\
\hline Electr. machinery & 3.5 & 3.8 & 5.9 & 39.0 & 2.3 \\
\hline Radio TV Communication equipment & 1.3 & 1.5 & 2.0 & 39.5 & 2.1 \\
\hline Precision instruments & 1.4 & 1.6 & 2.2 & 39.1 & 2.2 \\
\hline Motor vehicles & 1.1 & 1.3 & 1.2 & 41.4 & 1.5 \\
\hline Other transport equip. & 0.9 & 0.7 & 0.2 & 25.2 & 0.4 \\
\hline Furniture & 6.5 & 5.6 & 1.5 & 31.0 & 0.3 \\
\hline Recycling & 0.0 & 0.0 & 0.0 & 57.1 & 0.0 \\
\hline TOTAL MANUFACTURING & 89.4 & 88.5 & 68.2 & 35.7 & 1.1 \\
\hline Computer Services & 1.9 & 2.1 & 4.2 & 39.2 & 3.1 \\
\hline R\&D services & 0.1 & 0.1 & 0.2 & 36.0 & 4.0 \\
\hline Other business services & 8.6 & 9.3 & 27.4 & 39.3 & 4.5 \\
\hline TOT BUSINESS SERVICES & 10.6 & 11.5 & 31.8 & 39.3 & 4.2 \\
\hline TOTAL & 100.0 & 100.0 & 100.0 & 36.0 & 1.4 \\
\hline
\end{tabular}

Source: OECD, based on country reports. 
Annex Table 4. Netherlands: growing and high-growth firms by industry

Percentages

\begin{tabular}{|c|c|c|c|c|c|}
\hline & \multicolumn{3}{|c|}{ Distribution across sectors } & \multicolumn{2}{|c|}{ Distribution within sectors } \\
\hline & All firms & Growing firms & $\begin{array}{l}\text { High-growth } \\
\text { firms }\end{array}$ & $\begin{array}{l}\text { Growing firms } \\
\text { as share of all } \\
\text { firms }\end{array}$ & $\begin{array}{l}\text { High-growth } \\
\text { firms as share } \\
\text { of all firms } \\
\end{array}$ \\
\hline & $\mathrm{A}$ & $\mathrm{B}$ & $\mathrm{C}$ & $\mathrm{D}$ & $\mathrm{E}$ \\
\hline Horticulture and fishery & 0.8 & 0.8 & 1.0 & 57.0 & 6.2 \\
\hline Manufacturing & 27.7 & 25.5 & 25.0 & 56.0 & 4.7 \\
\hline Food \& beverages industries & 3.9 & 4.4 & 6.0 & 68.0 & 8.0 \\
\hline Chemical industry & 2.9 & 2.8 & 4.0 & 59.0 & 7.2 \\
\hline Metal industry & 13.5 & 11.8 & 10.0 & 53.0 & 3.8 \\
\hline Other manufacturing & 7.4 & 6.4 & 5.0 & 53.0 & 3.5 \\
\hline Public utilities & 0.4 & 0.3 & 0.0 & 49.0 & 0.0 \\
\hline Construction & 15.4 & 14.2 & 9.0 & 56.0 & 3.0 \\
\hline Garages & 3.1 & 3.0 & 1.0 & 60.0 & 1.7 \\
\hline Wholesale trade & 16.4 & 17.8 & 14.0 & 66.0 & 4.4 \\
\hline Retail trade & 7.3 & 8.3 & 11.0 & 69.0 & 7.8 \\
\hline Hotel \& catering industries & 3.3 & 2.9 & 1.0 & 53.0 & 1.6 \\
\hline Transport & 8.8 & 9.4 & 9.0 & 65.0 & 5.3 \\
\hline Banking and insurance & 2.6 & 2.8 & 5.0 & 65.0 & 10.1 \\
\hline Real estate agencies & 0.5 & 0.5 & 0.0 & 60.0 & 0.0 \\
\hline Business services & 9.2 & 10.2 & 18.0 & 67.0 & 10.2 \\
\hline Legal services / accountancy & 1.0 & 1.1 & 1.0 & 67.0 & 5.4 \\
\hline Engineering services & 3.3 & 3.5 & 6.0 & 65.0 & 9.4 \\
\hline Software services & 1.6 & 1.8 & 5.0 & 70.0 & 16.8 \\
\hline Advertising & 0.7 & 0.7 & 0.0 & 58.0 & 0.0 \\
\hline Other business services & 2.6 & 3.0 & 6.0 & 69.0 & 11.8 \\
\hline Renting of movables & 0.5 & 0.5 & 1.0 & 71.0 & 11.2 \\
\hline Cleaning services & 2.5 & 2.4 & 5.0 & 57.0 & 10.3 \\
\hline Personal services & 1.4 & 1.3 & 0.0 & 56.0 & 0.0 \\
\hline Total & 100.0 & 100.0 & 100.0 & 60.8 & 5.2 \\
\hline
\end{tabular}

Source:OECD, based on country reports. 
Annex Table 5. Spain: growing and high-growth firms by industry Percentages

\begin{tabular}{|c|c|c|c|c|c|}
\hline & \multicolumn{3}{|c|}{ Distribution across sectors } & \multicolumn{2}{|c|}{ Distribution within sectors } \\
\hline & All firms & Growing firms & $\begin{array}{l}\text { High-growth } \\
\text { firms }\end{array}$ & $\begin{array}{c}\text { Growing firms } \\
\text { as share of all } \\
\text { firms }\end{array}$ & $\begin{array}{l}\text { High-growth } \\
\text { firms as share } \\
\text { of all firms }\end{array}$ \\
\hline & $\mathrm{A}$ & $\mathrm{B}$ & $\mathrm{C}$ & $\mathrm{D}$ & $E$ \\
\hline Basic metals & 2.2 & 1.4 & 1.7 & 19.2 & 7.7 \\
\hline Non-metal. mineral prod. & 6.7 & 6.2 & 8.5 & 29.1 & 12.7 \\
\hline Chemical ind. & 7.3 & 8.7 & 11.0 & 37.2 & 15.1 \\
\hline Metal prod. & 9.9 & 10.0 & 6.8 & 31.9 & 6.9 \\
\hline Machinery \& mech. equip. & 6.5 & 5.4 & 5.9 & 26.3 & 9.2 \\
\hline Office and computing equip. & 0.2 & 0.3 & 0.0 & 50.0 & 0.0 \\
\hline Electr. \& electro. machinery & 9.1 & 10.8 & 13.6 & 37.4 & 15.0 \\
\hline Motor vehicles & 4.6 & 4.1 & 8.5 & 27.8 & 18.5 \\
\hline Other transport equip. & 2.3 & 0.8 & 0.8 & 11.1 & 3.7 \\
\hline Food, bever. \& tobacco & 16.9 & 21.1 & 21.2 & 39.4 & 12.6 \\
\hline Textiles & 4.2 & 3.3 & 1.7 & 24.5 & 4.1 \\
\hline Leather & 0.9 & 0.8 & 0.0 & 27.3 & 0.0 \\
\hline Footwear, wearing app. \& other & 8.5 & 6.2 & 2.5 & 23.0 & 3.0 \\
\hline Wood \& cork & 5.6 & 5.1 & 3.4 & 28.8 & 6.1 \\
\hline Paper, graphic arts \& publishing & 7.5 & 7.9 & 6.8 & 33.0 & 9.1 \\
\hline Rubber \& plastics & 4.9 & 5.7 & 6.8 & 36.2 & 13.8 \\
\hline Other manufacturing ind. & 2.6 & 2.2 & 0.8 & 25.8 & 3.2 \\
\hline TOTAL & 100.0 & 100.0 & 100.0 & 31.4 & 10.1 \\
\hline
\end{tabular}




\section{METHODOLOGICAL ANNEX}

\section{PARTICIPANTS}

Seven countries participated in the project. Their reports were prepared by :

\section{France•Philippe MUSTAR}

Centre de Sociologie de l'Innovation (CSI)

Ecole Nationale Supérieure des Mines de Paris (ENSMP)

Canada (Quebec)•Pierre-André JULIEN

Bombardier Chair in Management of Technological Change in SMEs.

-Martin MORIN

Research Institute on SMEs - University of Quebec - Trois-Rivières

Italy•Alberto BRAMANTI

- Michele SCARPINATO

CERTeT - University Luigi Bocconi - Milan

Netherlands`HJ. HEERES

-W.H.I. VERHOEVEN

Small Business Research \& Consultancy - EIM

Spain•José L. CALVO

- José LORENZO

Department of Economic Analysis - UNED - Madrid

Sweden•Per DAVIDSSON

Jönköping International Business School - Jönköping University

-Frederic DELMAR

Entrepreneurship \& Small Business Research Institute (ESBRI)

Germany•Vera LESSAT

- Michael WOYWODE

Centre for European Economic Research (ZEW)

(Zentrum für Europaïsche Wirtschaftsforschung) - Mannheim 


\section{STATISTICAL SOURCES}

\section{Nature of sources used in each country}

The data came from various sources: survey findings, census, trade registers or commercial data banks. Table A.1 shows the sources used by each country.

The main source of data for France was the Annual Survey of the Statistics Service (SESSI) of the Ministry of Industry. The Ministry of Research provided the information that was missing concerning R-D expenditure, while INSEE supplied the data that was missing concerning the independence of firms Data were matched using the identification number of firms.

In Canada, two complementary data banks were used. The Scott data bank provided data on firms in 1990, and the Quebec Industrial Research Centre (CRIQ), data for firms in 1996. Firms in the first and second database were first matched by their telephone number, and then by their name and address. The telephone number seemed the best way of matching firms even though it had some drawbacks.

Also, the coverage of the two data banks was not the same, one (Scott) having a national coverage, the other being confined to Quebec Province (CRIQ). A number of firms are registered in the former but not in the latter, especially firms of national scope, i.e. the bigger ones. Matching by telephone number thus underestimated the survival rate of large and medium-sized firms. Firms were then matched using the Scott register for 1997; this made it possible to find nearly $43 \%$ of firms with more than 100 employees, which still existed in mid-1996 but which had not been matched the first time round.

The Canadian sample gives a very good estimate of the population of firms that survived from 1990 to 1996. However, it was only possible to do the second round matching on firms with more than 100 employees, which means that part ${ }^{14}$ of the firms with 20 to 99 employees were not matched and that their survival and growth rates are thus under-stated.

In Italy, the data come from a single source, the Excelsior databank, which is run jointly by the National Federation of Italian Chambers of Commerce (UNIONCAMERE) and the Ministry of Labour. The UNIONCAMERE keeps a register on which every new firm is obliged to enrol. The register thus includes all Italian firms.

The Netherlands also used only one source - the REACH (Review and Analysis of Companies in Holland) database, which is likewise based on Chamber of Commerce registers. In Holland, firms with more than 2 employees are required to submit annual statements of accounts to the Chambers of Commerce. The data supplied by companies thus made it possible to construct a stratified sample broken down by sector and size. The results of this sample were then extended to the rest of the country using data from the Central Statistical Bureau.

The Spanish case study is based on data from the survey of business strategies commissioned by the Ministry of Industry and Energy. A number of firms were questioned every year between 1990 and 1994. The panel of firms comprised a stratified sample of firms with less than 200 employees and all firms with more than 200 employees.

In Sweden, the data were provided by Statistic Sweden. They come from three different sources: the tax authorities, the Patents and Company Registration Office (PRV), and mandatory surveys. The registers are complete in that all firms have to appear in them, and they are updated every year. A specific data set for the purposes of the study was compiled by combining several registers. 
The German case study is based on two data sets, the Mannheimer Unternehmenspanel (MUP) and the Mannheimer Innovation Panel (MIP). Note that the MUP and MIP concern only West German firms.

The source for MUP data is the credit rating agency CREDITREFORM. Data are collected in two ways: firstly, they are supplied on a voluntary basis by firms; secondly, CREDITREFORM itself registers new firms and collects data on them.

MIP data come from four successive rounds of surveys on innovation, ${ }^{15}$ which were conducted between 1992 and 1995. The firms, which had to fill out a questionnaire, were selected using the MUP data. However, the data provided by these surveys are only annual. In keeping with the dynamic approach of the study of high-growth SMEs, the sample of firms taken from the MIP was thus confined to those which had responded to the survey at least twice.

An important point is that the MUP and, by extension, the MIP, are samples of firms that cannot be considered representative of the total population of West German firms. The MUP comprises a smaller proportion of small firms (less than 250 employees) than large ones. Similarly, in the case of the MIP, the fact of conducting the survey by means of a questionnaire leads to self-selection and consequent overrepresentation of innovative firms.

These two sources also have a number of characteristics that make comparison difficult; this obliged the German experts to use them separately. In this sense, Germany is a case apart. The firms in the MUP come from the entire private sector, whereas those in the MIP are only from manufacturing and business services. The dynamics of job creation in services by itself explains the average employment growth rate, positive for all the firms from the MUP but negative for those from the MIP. Similarly, the average size of firms in the is less than 280 employees whereas that of firms in the MIP is well over 1000 employees.

The specific national features of the sources obviously influence the findings. The sources differ with respect to: the selection of firms (whole population or samples); the degree to which the case studies are representative; sectoral coverage (manufacturing sector only or manufacturing plus services); the periods covered. Table A.2 summarises the differences between the national sources.

\section{METHOD OF ANALYSIS}

\section{Selecting firms for the sample}

The following describes the methodological guidelines according to which country studies were to be conducted. The firm, as opposed to an establishment or group should be used as a statistical unit. This limits the possibility to monitor external growth processes (creation, mergers and acquisitions).

Starting with the population of firms available in national data banks samples of firms were selected (Figure A3).

The size of the firm was to be defined at the beginning of the period and in terms of the number of employees. The lower limit of the size range was set at 20 employees. All firms below this threshold were therefore excluded from the study. The "permanent" firms were then selected from the resultant sample. These were firms, which existed at the beginning of the period and had survived throughout the period. Firms created or wound up during the period were therefore excluded. To some extent, such permanence is already in itself a criterion of success.

The dynamics of new start-ups, which may be a source of new jobs, is not taken into account. This methodological approach also disregards mergers and acquisitions and their impact on employment. 
National data do not normally allow a distinction to be drawn between internal or "organic" growth, arising from genuine expansion of a firm, and external growth attributable to mergers and acquisitions.

These permanent firms meeting the minimum size requirements therefore constitute the population reviewed in case studies. This population may be broken down into two sub-populations: firms which have stagnated or whose overall number of employees has declined between the first and last year studied; and firms which in contrast have seen an increase in the number of employees over the same period.

The national experts then attempted to identify those firms among this group of job-creating firms, which experienced the highest rate of growth. This dynamic minority constitutes the population of "highgrowth" firms.

\section{Choice of a growth indicator}

Expansion and contraction of firms is analysed here in terms of the creation of jobs, the difference between the number of salaried employees at the end of the period and the number of salaried employees at the beginning of the period.

To identify high-growth firms, a measurement of growth (called the "Mustar" index) was applied. This index is the product of the relative and the absolute variation in employment.

$\mathrm{X}_{\mathrm{tn}}$

Mustar index $=\left(X_{\mathrm{tn}}-\mathrm{X}_{\mathrm{to}}\right) \mathrm{x}$

$\mathrm{X}_{\mathrm{t} 0}$

$\left(\mathrm{X}_{\mathrm{t}}=\right.$ number of employees at $\mathrm{t}$ with $\mathrm{n}$ and 0 standing for the beginning and end of the period)

The firms were then classified in decreasing order according to the value of their Mustar growth index. Based on this ranking, high-growth firms were defined as the $10 \%$ of the firms with the largest value of the Mustar index.

\section{Problems with implementation}

Despite these directives, major methodological differences remain and the present analysis is faced with the problem of harmonisation and consistency. The results obtained in each country are strongly marked by these differences. Table A.5 summarises the various discrepancies in the case studies.

The size of firms should be assessed at the beginning of the period. In the Netherlands, the reference size is the size of the firm at the end of the period. The Netherlands study therefore includes smaller firms (fewer than 20 employees) which experienced growth in the number of employees and excludes firms with more than 20 employees in which the number of employees had fallen. In other words, compared with other countries, this method of selection encourages the appearance of a larger number of dynamic firms in the category of the smallest firms. In Sweden, the size of firms is reassessed every year. In theory, the same firm may therefore appear in as many different size categories as there are statistical years in the period. While admittedly this is the most precise method and provides particularly interesting information regarding the interclass mobility of firms, it also has the disadvantage of producing results that cannot be readily compared with those of other countries.

The lower limit on the size of firms was set at 20 employees. In Spain, the lower limit is around ten employees; in Germany, the MUP and MIP databases list all firms indiscriminately without any reference 
to size. At this level, such differences are not negligible. The behaviour of small firms in terms of management, strategy and therefore employment can vary substantially. However, the case studies do provide a number of results by size class. This breakdown enables one to limit some conclusions solely to firms with more than 20 employees. Not all countries based their growth estimates on the same indicators (Table A7). Italy and Sweden preferred to use the Birch index rather than the Mustar index. Germany estimated growth in employment by means of annual percentage rates.

The high-growth threshold is also a divisive factor in that Canada, Italy, the Netherlands and Sweden set it at 5\% instead of the $10 \%$ agreed. Also, the 10\% threshold should have been applied to a reference population consisting solely of growing firms. However, the Netherlands, Spain and Sweden selected highgrowth firms from the larger population of permanent firms. The number of firms considered to be growing strongly is therefore multiplied commensurately. However, the results observed in all countries have shown there to be a fairly even distribution of permanent firms between the sub-population in which employment is growing and that in which it is declining.

The Italian experts set the high-growth threshold at 5\%. The reference population is that of firms in the manufacturing sector with between 20 and 499 employees. This allowed determination of a Birch growth index below which these firms were no longer considered to be growing strongly. This index was then applied to large manufacturing firms with over 500 employees and to firms in the service sector. As a result, it is harder to assess the share accounted for by this set of high-growth firms in the population of the initial study. The Italian results nonetheless showed that this high-growth population accounted for more or less $10 \%$ of the basic permanent population and, by extension, $20 \%$ of the growth population. In this respect, the situation of Italy would be closer to that of Spain. 
DSTI/DOC(2000)3

Table A.1. Sources used in the country studies

\begin{tabular}{|c|c|c|c|c|c|c|c|}
\hline & France & Canada (Quebec) & Italy & Netherlands & Spain & Sweden & Germany \\
\hline Source 1 & $\begin{array}{c}\text { Annual } \\
\text { Business } \\
\text { Survey of the } \\
\text { Statistics } \\
\text { Service (SESSI) } \\
\text { of the Ministry of } \\
\text { Industry }\end{array}$ & $\begin{array}{c}\text { SCOTT databank } \\
\text { "Register of } \\
\text { Quebec } \\
\text { Manufacturers" } \\
16^{\text {th }} \text { edition } \\
1990-91\end{array}$ & $\begin{array}{c}\text { EXCELSIOR } \\
\text { database } \\
\text { Run jointly by the } \\
\text { UNIONCAMERE } \\
\text { (Italian Federation of } \\
\text { Chambers of } \\
\text { Commerce) and the } \\
\text { Ministry of Labour }\end{array}$ & $\begin{array}{c}\text { REACH } \\
\text { databank: } \\
\text { Review and } \\
\text { Analysis of } \\
\text { Companies in } \\
\text { Holland }\end{array}$ & $\begin{array}{l}\text { Business Strategy } \\
\text { Survey } \\
\text { (ESEE / 1990-94) } \\
\text { Ministry of Industry } \\
\text { and Energy }\end{array}$ & $\begin{array}{c}\text { Registers of the } \\
\text { National } \\
\text { Statistical } \\
\text { Bureau }\end{array}$ & $\begin{array}{c}\text { Mannheimer } \\
\text { Innovation Panel } \\
\text { (MIP) } \\
\text { Survey on innovation } \\
\text { (ZEW\&INFAS) for the } \\
\text { Ministry of Education, } \\
\text { Science, Research } \\
\text { and Technology } \\
\text { (BMBF) }\end{array}$ \\
\hline Source 2 & $\begin{array}{l}\text { R-D Survey } \\
\text { Ministry of } \\
\text { Research }\end{array}$ & $\begin{array}{l}\text { Databank of the } \\
\text { Quebec Industrial } \\
\text { Research Centre } \\
\text { (CRIQ) } \\
1996\end{array}$ & - & - & - & - & $\begin{array}{c}\text { Mannheimer } \\
\text { Unternehmens } \\
\text { Panel } \\
\text { (MUP)Databank of } \\
\text { a credit rating } \\
\text { agency } \\
\text { (CREDITREFORM) }\end{array}$ \\
\hline Source 3 & $\begin{array}{c}\text { Liaisons } \\
\text { Financières } \\
\text { (LIFI) } \\
\text { Institut National } \\
\text { de Statistiques } \\
\text { (INSEE) }\end{array}$ & - & - & - & - & - & - \\
\hline $\begin{array}{c}\text { Type of } \\
\text { data }\end{array}$ & Survey findings & $\begin{array}{l}\text { Commercial } \\
\text { information } \\
\text { databanks }\end{array}$ & $\begin{array}{l}\text { Commercial } \\
\text { registers }\end{array}$ & $\begin{array}{l}\text { Commercial } \\
\text { registers }\end{array}$ & $\begin{array}{l}\text { Annual survey } \\
\text { findings }\end{array}$ & $\begin{array}{l}\text { Census } \\
\text { registers }\end{array}$ & $\begin{array}{l}\text { Survey findings } \\
\text { and business } \\
\text { databanks }\end{array}$ \\
\hline Notes & $\begin{array}{l}\text { Survey findings } \\
\text { were compared } \\
\text { by means of the } \\
\text { identification } \\
\text { number of firms }\end{array}$ & $\begin{array}{l}\text { Data in the two } \\
\text { data banks were } \\
\text { matched twice. }\end{array}$ & $\begin{array}{c}\text { Data were } \\
\text { compared with } \\
\text { those of the } \\
\text { National Social } \\
\text { Security Institute } \\
\text { (NISS) }\end{array}$ & $\begin{array}{l}\text { Findings related } \\
\text { to the total } \\
\text { population by } \\
\text { means of data of } \\
\text { the Central } \\
\text { Statistical } \\
\text { Bureau }\end{array}$ & $\begin{array}{l}\text { Sample of firms } \\
\text { with less than } 200 \\
\text { employees }+ \text { all } \\
\text { firms with more } \\
\text { than } 200 \\
\text { employees }\end{array}$ & $\begin{array}{l}\text { A specific data } \\
\text { set for the study } \\
\text { was created by } \\
\text { combining } \\
\text { several registers }\end{array}$ & $\begin{array}{l}\text { Samples are not } \\
\text { comparable and } \\
\text { are not } \\
\text { representative }\end{array}$ \\
\hline
\end{tabular}

Source : Phase I preliminary reports - April 1998. 
DSTI/DOC(2000)3

Table A.2. Discrepancies between country sources and level of impact on the findings

\begin{tabular}{|c|c|c|c|c|c|c|c|c|}
\hline & France & $\begin{array}{c}\text { Canada } \\
\text { (Quebec) }\end{array}$ & Italy & Netherlands & Spain & Sweden & $\begin{array}{c}\text { Germany } \\
\text { (MUP) }\end{array}$ & $\begin{array}{c}\text { German } \\
\text { (MIP) }\end{array}$ \\
\hline Selection of firms & $\begin{array}{c}\text { Whole } \\
\text { population }\end{array}$ & Sample & $\begin{array}{c}\text { Whole } \\
\text { population }\end{array}$ & Sample & Sample & $\begin{array}{c}\text { Whole } \\
\text { population }\end{array}$ & Sample & Sample \\
\hline Representative & Yes & Yes & Yes & Yes & Yes & Yes & Yes & Yes \\
\hline \multirow[t]{4}{*}{ Sectoral cover } & $\begin{array}{l}\text { Manufact- } \\
\text { uring }\end{array}$ & $\begin{array}{l}\text { Manufact- } \\
\text { uring }\end{array}$ & $\begin{array}{l}\text { Manufact- } \\
\text { uring }\end{array}$ & $\begin{array}{l}\text { Manufact- } \\
\text { uring }\end{array}$ & $\begin{array}{l}\text { Manufact- } \\
\text { uring }\end{array}$ & $\begin{array}{l}\text { Manufact- } \\
\text { uring }\end{array}$ & $\begin{array}{l}\text { Manufact- } \\
\text { uring }\end{array}$ & $\begin{array}{l}\text { Manufact- } \\
\text { uring }\end{array}$ \\
\hline & $\begin{array}{l}\text { Other } \\
\text { industries } \\
\text { (mining, } \\
\text { electricity, } \\
\text { gas, water) }\end{array}$ & - & - & $\begin{array}{l}\text { Other industries } \\
\text { (horticulture } \\
\text { and fisheries, } \\
\text { public services, } \\
\text { construction) }\end{array}$ & - & - & $\begin{array}{l}\text { Other industries } \\
\text { (all industries in } \\
\text { the private } \\
\text { sector) }\end{array}$ & - \\
\hline & - & - & - & $\begin{array}{c}\text { Distribution } \\
\text { (retail and } \\
\text { wholesale, } \\
\text { garages, hotels } \\
\text { and catering }\end{array}$ & - & Distribution & Distribution & - \\
\hline & - & - & $\begin{array}{l}\text { Services } \\
\text { (business } \\
\text { services) }\end{array}$ & $\begin{array}{l}\text { Services } \\
\text { (transport, } \\
\text { banking- } \\
\text { insurance, real } \\
\text { estate, } \\
\text { business } \\
\text { services, other } \\
\text { services) }\end{array}$ & - & $\begin{array}{c}\text { Services } \\
\text { (the entire } \\
\text { private sector) }\end{array}$ & $\begin{array}{c}\text { Services } \\
\text { (the entire } \\
\text { private sector }\end{array}$ & $\begin{array}{c}\text { Services } \\
\text { (business } \\
\text { services) }\end{array}$ \\
\hline \multicolumn{9}{|l|}{ Periods covered } \\
\hline Date & $1985-94$ & $1990-96$ & $1990-95$ & $1989-94$ & 1990-94 & 1987-96 & 1992-95 & 1992-95 \\
\hline Duration & 9 years & 6 years & 5 years & 5 years & 4 years & 9 years & 3 years & 3 years \\
\hline
\end{tabular}

Source : Phase I preliminary reports - April 1998. 
Figure A3. Illustration of the selection procedure

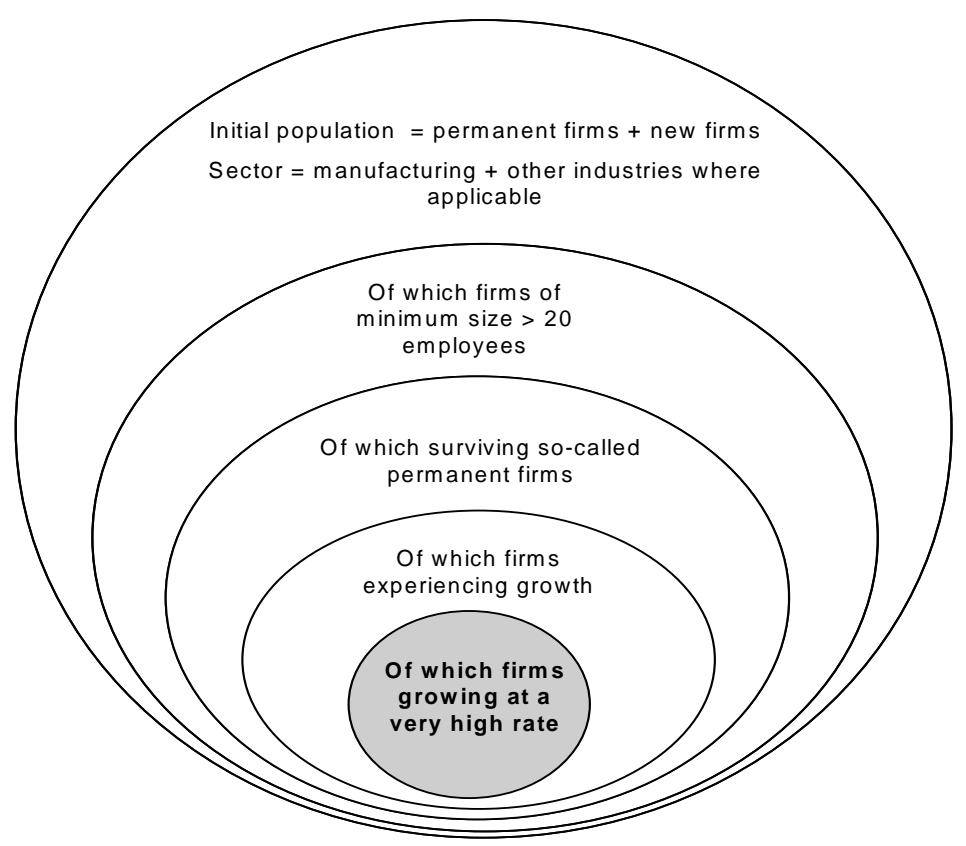


Table A.5. Divergences between the firm selection criteria used by countries and the initial directives

DSTI/DOC(2000)3

\begin{tabular}{|c|c|c|c|c|c|c|c|c|c|}
\hline & $\begin{array}{c}\text { OECD } \\
\text { directives }\end{array}$ & France & $\begin{array}{l}\text { Canada } \\
\text { (Quebec) }\end{array}$ & Italy & Netherlands & Spain & Sweden & $\begin{array}{l}\text { Germany } \\
\text { (MUP) }\end{array}$ & $\begin{array}{l}\text { Germany } \\
\text { (MIP) }\end{array}$ \\
\hline First selection criterior & & & & & & & & & \\
\hline $\begin{array}{l}\text { Minimum size of firm } \\
\text { Date of observation }\end{array}$ & $\begin{array}{l}\text { Beginning of } \\
\text { period }\end{array}$ & Idem & Idem & Idem & $\begin{array}{l}\text { End of } \\
\text { period }\end{array}$ & Idem & $\begin{array}{l}\text { End of } \\
\text { period }\end{array}$ & Idem & Idem \\
\hline Lower limit & 20 employees & Idem & Idem & Idem & Idem & $\begin{array}{c}10 \\
\text { employees }\end{array}$ & Idem & No limit & No limit \\
\hline $\begin{array}{l}\text { Second selection } \\
\text { criterion }\end{array}$ & $\begin{array}{l}\text { Survival } \\
\text { throughout } \\
\text { period }\end{array}$ & Idem & Idem & Idem & Idem & Idem & $\begin{array}{l}\text { + creations } \\
\text { >20 empl. } \\
\text { In } 1996\end{array}$ & Idem & Idem \\
\hline
\end{tabular}

Source: Preliminary Phase I reports, April 1998.

Table A.6. Comparison of class sizes adopted by countries

\begin{tabular}{|c|c|c|c|c|c|c|c|c|}
\hline & France & $\begin{array}{c}\text { Canada } \\
\text { (Quebec) }\end{array}$ & Italy & Netherlands & Spain & Sweden & $\begin{array}{c}\text { Germany } \\
\text { (MUP) }\end{array}$ & $\begin{array}{c}\text { Germany } \\
\text { (MIP) }\end{array}$ \\
\hline First class & $20-49$ & $20-49$ & $20-49$ & $20-49$ & $10-21$ & $20-250$ & $0-9$ & $0-24$ \\
\hline Second class & $50-99$ & $50-99$ & $50-99$ & $50-99$ & $21-50$ & $250+$ & $10-24$ & $25-99$ \\
\hline Fourth class & $250-499$ & $200-499$ & $200-499$ & $200-499$ & $101-200$ & & $50-99$ & $250-499$ \\
\hline Fifth class & $500-1999$ & $500+$ & $500-999$ & $500+$ & $201-500$ & & $100-249$ & $500-1000$ \\
\hline Sixth class & $2000+$ & & $1000+$ & & $501+$ & & $250-500$ & $1000+$ \\
\hline
\end{tabular}

Source: Preliminary Phase I reports, April 1998. 
Table A.7. Points on which growth indices diverge between countries

\begin{tabular}{|c|c|c|c|c|c|c|c|c|c|}
\hline & OECD directives & France & $\begin{array}{l}\text { Canada } \\
\text { (Quebec) }\end{array}$ & Italy & Netherlands & Spain & Sweden & $\begin{array}{c}\text { Germany } \\
\text { (MUP) }\end{array}$ & $\begin{array}{l}\text { Germany } \\
\text { (MIP) }\end{array}$ \\
\hline Type of indicator & Mustar index & Idem & Idem & Birch index & Idem & Idem & Birch index & $\begin{array}{l}\text { Logarithmic } \\
\text { AARG }^{1}\end{array}$ & $\begin{array}{l}\text { Logarithmic } \\
\text { AARG }^{1}\end{array}$ \\
\hline $\begin{array}{l}\text { High-growth } \\
\text { threshold }\end{array}$ & $10 \%$ & Idem & $5 \%$ & $5 \%$ & $5 \%$ & Idem & $5 \%$ & Idem & Idem \\
\hline $\begin{array}{l}\text { Reference } \\
\text { population }\end{array}$ & Growth firms & Idem & Idem & $\begin{array}{l}\text { Firms in the } \\
\text { manufacturing } \\
\text { sector with } \\
\text { between } 20 \\
\text { and } 499 \\
\text { employees }\end{array}$ & $\begin{array}{l}\text { Permanent } \\
\text { firms }\end{array}$ & $\begin{array}{l}\text { Permanent } \\
\text { firms }\end{array}$ & $\begin{array}{l}\text { Permanent } \\
\text { firms }\end{array}$ & Idem & Idem \\
\hline
\end{tabular}

1. Average annual rate of growth

Source: Preliminary Phase I reports, April 1998.

Table A.8. Size of study populations and sub-populations by country

\begin{tabular}{|lcccccc|}
\hline Number of firms & France & $\begin{array}{c}\text { Canada } \\
\text { (Quebec) }\end{array}$ & Italy & $\begin{array}{c}\text { Netherlands } \\
\text { Spain }\end{array}$ & $\begin{array}{c}\text { Sweden } \\
\text { (MIP) }\end{array}$ \\
\hline $\begin{array}{l}\text { Permanent population } \\
\text { Growth population }\end{array}$ & 10691 & 2977 & 32653 & 23416 & 1174 & 8173 \\
$\begin{array}{l}\text { High-growth } \\
\text { population }\end{array}$ & 5034 & 1496 & 18256 & 14228 & 369 & 3644 \\
\hline
\end{tabular}

Source: Preliminary Phase I reports, April 1998. 


\section{NOTES}

1. See, for example, OECD (1994a; 1997a).

2. For example, Caballero et al. (1997), in a study of employment dynamics, conclude that "by far the dominant source of microeconomic employment changes is idiosyncratic shocks, and these play a key role in mapping aggregate shocks into actual employment responses". Further, "The results [...] lend support to the view that microeconomic heterogeneity is important not only for microeconomic issues but also for macroeconomics."

3. This discussion draws on $\operatorname{OECD}(1996 \mathrm{a})$.

4. For empirical results with different size allocation methods see for example, Davis et al. (1996), Picot et al. (1994), or Wagner (1995). A fuller treatment of the question can also be found in Davidsson et al. (1998) and Carree and Klomp (1996).

5. Mean growth rates of employment over individual firms as shown in Table 2 are different from net job creation rates as defined earlier. While the former are unweighted averages of growth rates across units, the latter correspond to weighted averages of growth rates across units.

6. This is typically done with regression analysis. Examples of such work include Evans (1987), Davidsson et al. (1995), Davis et al. (1996) or Harhoff et al. (1998).

7. A fuller discussion of the role of new technology based firms and related policies, can be found in Chapter 7 of OECD (1998b).

8. $\quad$ For a survey of studies on entry, see Geroski (1995).

9. High-growth firms are then identified as those units with the largest value of $m$ (see Annex for details). Even when an unbiased measure is used so that large firms have the same a-priori or conditional probability of rapid growth as small ones, the overall (unconditional) probability of selecting a large firm into the sample of high growth firms is much smaller than the probability of selecting a small firm, simply because there are so many more small firms in the economy.

10. As in the assessment of the industry effects, the inference from Germany is based on results from a (probit) regression model that simultaneously examines the effects of age, size, industry, etc. on the probability of being a high-growth firm. Its results are therefore of a different nature from the partial analysis on which other country studies are based.

11. A qualification applies: because the country analyses are based on firm data, the entire activity of a highgrowth firm is ascribed to the region where it is registered. This can lead to an inaccurate picture if a firm has multiple establishments that are located in different parts of the country.

12. Following the literature (e.g. Stoneman, 1994), innovation is understood in a broad sense: it encompasses product innovation, process innovation, organisational innovation, changes in the materials and intermediate inputs used in the production process and changes in markets. 
13. A recent Dutch study (Baljé and Waasdrop, 1999) points to the role that governments can play in facilitating access to information tools which permit individual firms to position themselves against their counterparts in the same market or industry.

14. The Canadian experts estimated that $10 \%$ of firms with less than 100 employees could have been matched (compared with $43 \%$ for those with more than 100 employees, the proportion falling with the size of the firm).

15. The project is funded by the Ministry of Education, Science, Research and Technology (BMBF). 